\title{
Risk assessment of herbicides and booster biocides along estuarine continuums in the Bay of Vilaine area (Brittany, France)
}

\author{
Th. Caquet ${ }^{1, *}$, M. Roucaute ${ }^{1}$, N. Mazzella ${ }^{2}$, F. Delmas ${ }^{2}$, C. Madigou ${ }^{2}$, E. Farcy ${ }^{3}$, Th. Burgeot ${ }^{3}$, \\ J.-P. Allenou ${ }^{4}$, R. Gabellec ${ }^{4}$
}

\author{
${ }^{1}$ INRA, UMR985 Écologie et Santé des Écosystèmes, Équipe Écotoxicologie et Qualité des Milieux Aquatiques, \\ Agrocampus Ouest, 65 rue de Saint Brieuc, F-35042 Rennes Cedex, France \\ 2 IRSTEA, UR REBX, F-33612 Cestas Cedex, France \\ ${ }_{4}^{3}$ Ifremer, Unité Biogéochimie et Ecotoxicologie, BP 21105, F-44311 Nantes Cedex, France \\ ${ }^{4}$ Ifremer, Laboratoire Côtier Morbihan Pays de Loire, Nantes et La Trinité-sur-Mer, BP 86, F- 56470 La Trinité sur \\ Mer, France \\ *: Corresponding author : Th. Caquet, email address : Thierry.Caquet@rennes.inra.fr
}

\begin{abstract}
:
A 2-year study was implemented to characterize the contamination of estuarine continuums in the Bay of Vilaine area (NW Atlantic Coast, Southern Brittany, France) by 30 pesticide and biocide active substances and metabolites. Among these, 11 triazines (ametryn, atrazine, desethylatrazine, desethylterbuthylazine, desisopropyl atrazine, Irgarol 1051, prometryn, propazine, simazine, terbuthylazine, and terbutryn), 10 phenylureas (chlortoluron, diuron, 1-(3,4-dichlorophenyl)-3-methylurea, fenuron, isoproturon, 1-(4isopropylphenyl)-3-methylurea, 1-(4-isopropylphenyl)-urea, linuron, metoxuron, and monuron), and 4 chloroacetanilides (acetochlor, alachlor, metolachlor, and metazachlor) were detected at least once. The objectives were to assess the corresponding risk for aquatic primary producers and to provide exposure information for connected studies on the responses of biological parameters in invertebrate sentinel species. The risk associated with contaminants was assessed using risk quotients based on the comparison of measured concentrations with original species sensitivity distribution-derived hazardous concentration values. For EU Water Framework Directive priority substances, results of monitoring were also compared with regulatory Environmental Quality Standards. The highest residue concentrations and risks for primary producers were recorded for diuron and Irgarol 1051 in Arzal reservoir, close to a marina. Diuron was present during almost the all survey periods, whereas Irgarol 1051 exhibited a clear seasonal pattern, with highest concentrations recorded in June and July. These results suggest that the use of antifouling biocides is responsible for a major part of the contamination of the lower part of the Vilaine River course for Irgarol 1051. For diuron, agricultural sources may also be involved. The presence of isoproturon and chloroacetanilide herbicides on some dates indicated a significant contribution of the use of plant protection products in agriculture to the contamination of Vilaine River. Concentration levels and associated risk were always lower in estuarine sites than in the reservoir, suggesting that Arzal dam reduces downstream transfer of contaminants and favors their degradation in the freshwater part of the estuary. Results of the additional monitoring of two tidal streams located downstream of Arzal dam suggested that, although some compounds may be transferred to the estuary, their impact was probably very low. Dilution by marine water associated with tidal current was also a major factor of concentration reduction. It is concluded that the highest risks associated to herbicides and booster biocides concerned the freshwater part of the estuary and that its brackish/saltwater part was exposed to a moderate risk, although some substances may sometimes exhibit high concentration but mainly at low tide and on an irregular basis.
\end{abstract}

Keywords: Estuary ; Herbicides ; Booster biocides ; Species sensitivity distribution ; Risk quotient ; Atlantic Coast 


\section{Introduction}

Estuaries are major sites of anthropogenic activities. They are subject to high levels of disturbance from multiple stressors, including chemical pollution, with consequences on the dynamics of many estuarine and marine species (Johnson et al. 1998). A significant part of estuarine pollution originates from upstream but relationships between terrestrial sources and costal contamination are frequently neglected (Chapman and Wang 2001). Although, information about the presence and effects of pesticides in fresh- to marine water continuums remained rare for a long time (Ahel et al. 1992; Readman et al. 1993; Power et al. 1999), there is a growing evidence that riverine inputs contribute largely to the occurrence of pesticides, especially herbicides, in estuarine and coastal systems (Haynes et al., 2000; Shaw and Müller 2005; Lewis et al. 2009). Such compounds may be present in significant amounts at some critical periods (e.g., when reproduction of plant or animal species takes place; Steen et al. 2001; Noppe et al. 2007). For example, in a two-year study performed in the Scheldt estuary, Steen et al. (2001) monitored the fluxes of some herbicides (atrazine, simazine, alachlor and metolachlor), of desethylatrazine (DEA), of an insecticide (dichlorvos) and of an antifouling compound, Irgarol 1051 (active ingredient cybutryne), transported by the river towards the North Sea. They showed that the temporal trends of pesticide presence were related to their application period, except for metolachlor. Data suggested that downstream concentrations of pesticides in estuaries were generally lower that in upstream sites due to the dilution caused by mixing of river water with relatively uncontaminated seawater (depending on the tidal action), and to degradation and sorption to suspended matter and sediments (Steen et al. 2001). However, concentration levels were high enough to raise concern about their potential impact on estuarine organisms. In a threeyear survey in the same estuary, Noppe et al. (2007) showed that the highest concentrations were found for atrazine (from 10 to $736 \mathrm{ng} / \mathrm{L}$ in water) whereas simazine and terbuthylazine were detected at lower concentrations (from 13 to $313 \mathrm{ng} / \mathrm{L}$ and from 13 to $261 \mathrm{ng} / \mathrm{L}$ for simazine and terbuthylazine, respectively). Although these compounds have been banned in most European countries by the beginning of the 2000s, mother compounds and metabolites are still detected at quantifiable levels in many rivers, especially in France (SOES, 2011), and atrazine was still present in estuarine sediments of the Adriatic Sea eight years after the implementation of a total ban of its use in Italy (Carafa et al. 2007). In addition to pesticides, the extensive use of antifouling biocides on boat shells and other submerged surfaces was also responsible for the contamination of water and sediments by many toxic substances, especially booster biocides (e.g., Irgarol 1051; Hall and Gardinali 2004) used in combination with other compounds such as copper salts (Omae 2003). Some of these booster biocides have also been used as pesticides for agricultural use (e.g., diuron) leading to possible confusion in identifying contamination sources (Di Landa et al. 2009). There is evidence that these compounds were highly toxic for freshwater and marine autotrophs (Okamura et al. 2003), influencing key 
species like sea grasses (Chesworth et al. 2004) and corals (Owen et al. 2002). Quantitative assessment of the presence of these compounds in estuarine and coastal systems is therefore a matter of concern for many stakeholders involved in the conservation and exploitation of these areas (e.g., oyster or mussel farmers, fishermen).

The interpretation of pesticide monitoring studies in terms of risk for aquatic communities usually relies on the comparison of recorded concentrations with specific water quality criteria (WQC) or reference values such as predicted no-effect concentration (PNEC; Babut et al. 2003). Many authors have proposed to use Hazardous Concentrations (HCs) instead of PNECs (Smith and Cairns 1993; Maltby et al. 2005) for defining WQCs. HCs values are usually derived from species sensitivity distribution (SSD) constructed using acute (e.g., EC50) or chronic (e.g., no-observedeffect concentration - NOEC) toxicity data. Once a SSD has been established, an HC5 (Hazardous Concentration for $5 \%$ of the species of a community) may be derived. It is usually considered as a safe concentration (van Leeuwen 1990). This strategy has been used, among other tools, in the EU for the definition of Annual Average- and Maximum Allowable Concentration-Environmental Quality Standards (AA- and MAC-EQS, respectively) values for a list of priority substances defined by the EU Water Framework Directive (EU 2008). This list includes atrazine, diuron, isoproturon and simazine. In addition, EQS values are currently proposed for cybutryne (active ingredient of Irgarol 1051; Rodriguez Romero 2011) but they have not been adopted yet. However, EQS values are still lacking for certain active substances (e.g., S-metolachlor, alachlor) and for degradation products (e.g., DEA). A limit of EQS is that substances are considered individually whereas environmental contamination is usually due to a mixture of compounds. When aquatic organisms are exposed to a mixture of pesticides, a significant effect may occur, even if the concentration of each individual compound is below the corresponding NOEC (Backhaus et al. 2000). In particular, this phenomenon has been described for aquatic primary producers exposed to herbicide mixtures (Faust et al. 1994, 2001; Arrhenius et al. 2004). Chèvre et al. (2006) proposed to overcome this difficulty in defining risk quotients of mixtures of herbicides with a similar mode of action using WQC derived from NOEC-based SSDs (HC5-95\%, i.e., the lower 95\% confidence limit of the HC5 determined on the basis of the NOEC-based SSD) under the hypothesis of the concentration addition model (Altenburger et al. 2000; Junghans et al. 2003; Backhaus et al. 2004). Using HC5-95\% values instead of HC5 allows to take into account the uncertainty of the HC5 estimation. Using this method, Chèvre et al. (2006) defined WQC for several triazine (but not for Irgarol 1051) and phenylurea herbicides but only for freshwater primary producers.

The question of the possibility of using data obtained with freshwater organisms to extrapolate to saltwater organisms remains open. Using results from acute toxicity tests to construct SSDs for a variety of substances, Leung et al. (2001) and Wheeler et al. (2002) showed that there was not a unique relationship between fresh- and saltwater sensitivity. 
Freshwater organisms tended to be more sensitive than their saltwater counterparts to ammonia and metals. An opposite trend was noticed for pesticides and narcotics. However, these results cannot be used to draw general conclusions because data for all categories of aquatic organisms were used (e.g., from algae to fish), species parity and representativeness were not identical (taxonomic diversity was generally higher for freshwater datasets) and no herbicide was included in the panel of compounds considered. When possible, it is therefore necessary to compare the available datasets for fresh- and saltwater species to assess if it is possible to derive a common reference value for both types of ecosystems or if it is necessary to define different WQCs.

Information about the transfer of pesticides from continent to French coastal ecosystems are quite rare, although monitoring data showed the existence of a general contamination of streams and rivers by mixtures of pesticides, especially herbicides. Buisson et al. (2008) detected 6 herbicides in coastal and estuarine sites in Normandy, especially diuron and isoproturon. In Atlantic bays and estuaries, Munaron et al. (2006) reported diuron concentration up to 1 $\mu \mathrm{g} / \mathrm{L}$. With a $10,400 \mathrm{~km}^{2}$ area watershed, Vilaine is the most important river from northwestern France. About $60 \%$ of the watershed is used for intensive agricultural (e.g., wheat, maize) and livestock production. The downstream part of the river is characterized by the presence of Arzal dam that has been built in 1970 to regulate water flow and to prevent flooding of surrounding areas. Arzal dam is located $12 \mathrm{~km}$ upstream the outlet of the Vilaine. It is equipped with 5 gates and one lock used for leisure boats coming in and out of the Arzal-Camoël marina that has been settled up in the freshwater reservoir ( 20 millions $\left.\mathrm{m}^{3}\right)$ formed by the dam. Around 1,000 boats are permanently harboured in this marina. Changes in hydrodynamics associated with the building of Arzal dam increased the deposition of fine particles in the estuary which is heavily silted up. A drinking water plant has been built up $2 \mathrm{~km}$ upstream of the dam. It uses water from the Arzal reservoir to produce up to $100,000 \mathrm{~m}^{3}$ per day of tap water. Data from former monitoring programs showed that Vilaine estuary was moderately polluted by metals and persistent organic pollutants (POPs) and that pesticides were frequently detected at high levels in Vilaine upstream of Arzal reservoir (RNO 2004). Therefore, this area was selected by the EXECO French research consortium to implement a multidisciplinary research programme on the presence and effects of pesticides in a series of sites distributed along fresh- to marine water continuums. Focus was made on spring, which is a key period for the reproduction of many invertebrate species. This paper presents the results of the monitoring of pesticides in Arzal reservoir and in the Vilaine estuary obtained during this program and of the assessment of the corresponding risk for aquatic primary producers. Data on estuarine sentinel organisms (Mytilus edulis L.) are presented in a companion paper (Farcy et al. this issue, submitted).

\section{Material and methods}




\subsection{Sampling sites}

Three sampling sites were monitored in 2006 on the Vilaine continuum (Figure 1): Arzal (47³0'25.8" N, 02²3'20.4"

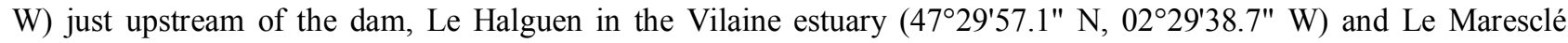
$\left(47^{\circ} 27^{\prime} 47.3^{\prime \prime} \mathrm{N}, 02^{\circ} 29^{\prime} 50.4^{\prime \prime} \mathrm{W}\right)$ in the Bay of Vilaine, outside of the presumed area of influence of Vilaine River. In 2007, Le Halguen station was replaced by another station, Les Granges (47³0'46.5" N, 02²9'13.0" W), that was more influenced by the Vilaine plume as deduced from field observations of water flow in the estuary during the first year of the study. In order to evaluate the possible contribution of other sources to the contamination of the Vilaine estuary, two tidal streams located on the northern bank of the estuary, Kerdavid River and Billiers River were monitored in 2007 with two sampling sites per stream, Le Marais $\left(47^{\circ} 32^{\prime} 31.1^{\prime \prime} \mathrm{N}, 02^{\circ} 25^{\prime} 24.3^{\prime \prime} \mathrm{W}\right)$ and Port de Billiers $\left(47^{\circ} 31^{\prime} 05.8^{\prime \prime} \mathrm{N}\right.$, $\left.02^{\circ} 29^{\prime} 56.7^{\prime \prime} \mathrm{W}\right)$ on Billiers River, and Kervor $\left(47^{\circ} 31^{\prime} 23.4^{\prime \prime} \mathrm{N}, 02^{\circ} 25^{\prime} 51.0^{\prime \prime} \mathrm{W}\right)$ and Kerdavid $\left(47^{\circ} 30^{\prime} 01.5^{\prime \prime} \mathrm{N}\right.$, $02^{\circ} 25^{\prime} 14.1^{\prime \prime}$ W) on Kerdavid River.

\subsection{Environmental parameters}

Data on daily flow at the outlet of Arzal dam were provided by the Institution d'Aménagement de la Vilaine which manages this infrastructure (Online Resource 1). Rainfall data recorded in the meteorological station of Theix $\left(47^{\circ} 38^{\prime} \mathrm{N}, 2^{\circ} 37^{\prime} \mathrm{W}\right)$ were provided by Meteo France (Online Resource 2). Water temperature, salinity and dissolved oxygen saturation were measured in situ on each sampling date and in each sampling site using portable probe apparatuses (WTW, Champagne au Mont d'Or, France for freshwater sites; Micrel, Villebon-sur-Yvette, France and Hach Lange France, Noisy le Grand, France, for estuarine sites). Water samples (5 L) from Arzal and from the four sampling sites located on tidal streams were collected in polyethylene bottles and brought back to the laboratory for chlorophyll $a$ and suspended solids concentration measurement. Subsamples $(500-750 \mathrm{~mL})$ were filtered through Whatman GF/C fiberglass filters (1.2- $\mu \mathrm{m}$ mesh size; Whatman International, Maidstone, UK) which were immersed overnight in $5 \mathrm{~mL}$ of an acetone/distilled water $(90 / 10, \mathrm{v} / \mathrm{v})$ mixture at $4{ }^{\circ} \mathrm{C}$ for pigment extraction. Chlorophyll $a$ was quantified spectrophotometrically (Specord 205, AnalytikJena AG, Jena, Germany) according to Lorenzen (1967). Suspended solids concentration was determined in $250 \mathrm{~mL}$ water subsamples filtered through pre-weighted oven-dried $\left(2 \mathrm{hrs}\right.$ at $500^{\circ} \mathrm{C}$ ) Whatman $\mathrm{GF} / \mathrm{C}$ fiberglass filters that were weighted again after $48 \mathrm{hrs}$ at $105^{\circ} \mathrm{C}$ according to the AFNOR (1996) method. Suspended solids and chlorophyll $a$ concentration in water samples collected in the Vilaine estuary were measured according to routine methods implemented by Ifremer coastal laboratories (Aminot and Chaussepied 1983 and Aminot and Kerouel 2004 for suspended solids and chlorophyll $a$, respectively).

\subsection{Sampling for pesticide residue analysis}


A refrigerated flow-triggered sampler was installed on Arzal dam but due to repeated malfunctions it was frequently impossible to analyse the corresponding samples. Therefore, most of the information were obtained using repeatedly collected point water samples. In 2006 sampling was performed from April 10 to July 24 (12 sampling dates) whereas in 2007, sampling was performed from April 03 to July 16 (12 sampling dates). Estuarine sites were sampled twice in 2006 (May 15 and July 10) and 8 times in 2007 (April 16, May 02, 14 and 28, June 12 and 18, July 02 and 16). On each date, samples were collected at low tide and, when possible, at high tide in order to evaluate the influence of sea level on the concentration of pesticide residues. Stations located on tidal streams were sampled 9 times (April 16 and 23, May 02, 14 and 28, June 12 and 18, July 02 and 16). Water samples were stored at $4^{\circ} \mathrm{C}$ and immediately transferred to the analytical laboratory.

\subsection{Pesticide residue analysis}

Pesticide residues were analysed using a multiresidue method based on off-line solid phase extraction followed by reversed-phase liquid chromatographic separation and electrospray triple quadrupole mass spectrometric detection (Mazzella et al. 2009; see Online Resource 3 for additional details). This technique allows the simultaneous determination of 30 active substances and metabolites: 11 triazines (ametryn, atrazine, cyanazine, atrazine-desethylDEA, terbuthylazine-desethyl-DET, atrazine-desisopropyl-DIA, Irgarol 1051, prometryn, propazine, simazine, terbuthylazine, terbutryn), 14 phenylureas (chlortoluron, diuron, 1-(3,4-dichlorophenyl)-3-methylurea-DCPMU, 1-(3,4dichlorophenyl)-urea-DCPU, fenuron, isoproturon, 1-(4-isopropylphenyl)-3-methylurea-IPPMU, 1-(4isopropylphenyl)-urea-IPPU, linuron, metobromuron, metoxuron, monolinuron, monuron, neburon) and 4 chloroacetanilides (acetochlor, alachlor, metolachlor, metazachlor).

Briefly, $200 \mathrm{~mL}$ of water samples ( $\mathrm{pH}$ adjusted to 7) were filtered using GF/F glass microfibre filters $(0.7 \mathrm{~mm}$ pore size) and $10 \mu \mathrm{L}$ of a stock solution (acetonitrile) containing $10 \mathrm{ng} / \mathrm{mL}$ of atrazine D5, diuron D6 and metolachlor D6 as internal standards were added. Preconcentration of the analytes was performed using solid-phase extraction (SPE) with Oasis HLB cartridges fitted to a VisiPrep 12-port manifold (Supelco, France). The conditioning, extraction and rinsing steps were carried out under a $400 \mathrm{~mm} \mathrm{Hg}$ vacuum. The cartridges were successively washed with methanol (10 mL), conditioned with HPLC grade water $(10 \mathrm{~mL})$ and loaded with water samples $(200 \mathrm{~mL})$. They were then rinsed with 20 $\mathrm{mL}$ of HPLC grade water and dried under a stream of nitrogen for 30 minutes. Elutions were achieved with $5 \mathrm{~mL}$ of methanol. The extracts were then dried under a gentle stream of nitrogen and dissolved in $1 \mathrm{~mL}$ of an acetonitrile:water (10:90, v/v) mixture prior to the HPLC-ESI-MS/MS analyses. The matrix effects were studied by spiking various waters (i.e., river and sea waters) with the chemicals of interest (Mazzella et al., 2009). The results showed that the samples with the highest conductivity (i.e., seawater) exhibited important matrix effects with signal suppressions. These matrix effects were strongly minimized by performing appropriate internal standardizations. The HPLC separation was 
performed on a Finnigan SpectraSYSTEM equipped with a Prontosil Spheribond ODS 2 column $(150 \times 4 \mathrm{~mm}, 3 \mu \mathrm{m})$ with a C18 $(10 \times 4 \mathrm{~mm}, 6 \mu \mathrm{m})$ guard column (Bischoff Chromatography, Germany). The injection volume was $50 \mu \mathrm{L}$ and elution was performed using a gradient of acetonitrile:water (10:90, v/v). The HPLC system was coupled with an API 2000 (Applied Biosystems/MDS SCIEX, France) triple quadrupole mass spectrometer equipped with a turboionspray source (ESI). The validated limits of quantification (LOQ) were $20 \mathrm{ng} / \mathrm{L}$ for triazines and $50 \mathrm{ng} / \mathrm{L}$ for phenylureas and chloroacetanilides. Both laboratory and analytical blanks were systematically carried out during the sample preparation and LC-MS/MS analysis steps for checking the absence of any cross contaminations. Moreover, fortified water samples (mineral water spiked at two concentration levels, with 40 and $200 \mathrm{ng} / \mathrm{L}$ of analytes) were extracted simultaneously during the preparation of the water samples collected on the field, ensuring the efficiency and the smooth progress of the extracting step.

\subsection{Construction of SSD curves and $\mathrm{HC}$ derivation}

The present study focused on ten substances that were regularly quantified in the samples collected in 2006 and 2007 : two phenylureas (diuron, isoproturon), three chloroacetanilides (acetochlor, alachlor, S-metolachlor), three triazines (atrazine, simazine, Irgarol 1510) and two atrazine metabolites (DEA and DIA). The EC50 and NOEC/EC10 data for each considered herbicide or metabolite were collected from databases (e.g., Agritox, ECOTOX, Footprint Pesticide Properties DataBase), from regulatory reports (e.g., registration monographs and reports) and from the scientific literature. Only data on primary producers such as algae and aquatic plants were used because they are the most sensitive species to the considered compounds (Chèvre et al. 2006). Only results from tests superior or equal to $24 \mathrm{~h}$ duration were accepted and only effects on growth, reproduction or survival were used as they can directly be related to population dynamics. Toxicity studies with endpoints related to biochemistry (e.g., chlorophyll content) or physiology (e.g., photosynthesis) were not taken into account. The complete data set is given in Online Resource 4. In most cases, data with taxonomic detail at the species level were used. In a few cases, the genus level was accepted, by assuming the same sensitivity within each genus (Maltby et al. 2005). When more than one toxicity value was found for a species, their geometric mean was calculated. When more than one data point was available for a given species, the data were weighed according to Duboudin et al. (2004) to construct the SSD curves. The EC50- or NOEC-SSD of each herbicide were fitted with a log-logistic regression (Newman et al. 2000; Wheeler et al. 2002; Chèvre et al. 2006). When less than 6 values were available, fitting was not performed du to insufficient data. When the number of data was comprised between 6 and 10, fitting of the SSD curve was performed but resulting values were considered only as indicative.

The criterion to determine whether HC5 estimates for fresh- and saltwater organisms were significantly different was nonoverlapping confidence intervals, and sensitivity distributions were compared using the two sample Kolmogorov- 
Smirnov test (Maltby et al., 2005). Comparison of sensitivity distributions was performed only when the size of the smallest sample was equal or superior to 5. When there was no differences in HC5 estimates and Kolmogorov-Smirnov test was passed successfully, we merged the two datasets to compute a common SSD for fresh- and saltwater primary producers.

\subsection{Computation of risk quotients}

The risk for primary producers was evaluated for each substance by computing the ratio between its measured environmental concentration and its HC5-95\% calculated using the NOEC-SSD (or EC50-SSD when not enough NOEC data were available to compute a NOEC-SSD) as follows (Chèvre et al. 2006):

$$
R Q_{i}=\frac{[C]_{i}}{(H C 5-95 \%)_{i}}
$$

Where $R Q_{i}$ is the risk quotient for substance $i,[C]_{i}$ is the measured environmental concentration of substance $i$ and $(H C 5-95 \%)_{i}$ is the lower $95 \%$ confidence limit of the HC5 determined for substance $i$ on the basis of the NOEC-SSD (or EC50-SSD when the number of NOEC values was too low).

For mixtures of substances exhibiting a similar mode of action, the mixture effect was predicted considering that for such mixture the concept of concentration addition applied (Altenburger et al. 2000). The values of the risk quotient for photosystem II inhibitors (triazines and phenylureas) and elongase inhibitors (chloroacetanilides) mixtures were computed as the sum of the values of the risk quotients of individual substances (Chèvre et al. 2006) :

$$
R Q_{m}=\sum_{i=1}^{n} R Q_{i}=\sum_{i=1}^{n}\left\lfloor\frac{[C]_{i}}{(H C 5-95 \%)_{i}}\right\rfloor
$$

Where $R Q_{m}$ is the risk quotient for the mixture, $R Q_{i}$ is the risk quotient for substance $i,[C]_{i}$ is the measured environmental concentration of substance $i$ and $(H C 5-95 \%)_{i}$ is the lower $95 \%$ confidence limit of the HC5 determined for substance $i$ on the basis of the NOEC-SSD (or EC50-SSD when the number of NOEC values was too low).

When $\mathrm{RQ}_{i}$ (respectively $\mathrm{RQ}_{\mathrm{m}}$ ) value is less than one, substance $i$ (respectively the mixture) presents an acceptable risk to the environment.

\subsection{Comparison with EQS values}

Although the sampling period did not cover a whole year, residue concentration values were compared with regulatory AA- and MAC-EQS for priority substances (alachlor, atrazine, diuron, isoproturon and simazine; EU 2008) or with 
currently proposed EQS values for Irgarol 1051 (Table 1). For estuarine sites, results obtained on a same date at low and high tide were averaged before comparison with EQS values. When the concentration value was less than the $\mathrm{LOQ}$, a value equal to $\mathrm{LOQ} / 2$ was used for the computations.

\subsection{Data analysis}

All the analysis were performed using R software (version 2.8.1). Results obtained on the same date for water physicochemical parameters in sampling sites located upstream and downstream of the tidal streams or within the Vilaine estuary were compared using Wilcoxon test for paired samples $(\alpha=0.05)$ using the R package stats. Computation of SSDs and HC values were performed using the R package $d r m$. Kolmogorov-Smirnov two samples tests $(\alpha=0.05)$ were performed using the R package fBasics.

\section{Results}

\subsection{Water physico-chemical parameters}

Results from the measurements performed in the various sampling sites suggested the existence of a sharp longitudinal gradient in salinity, especially in the Vilaine River (Table 2). Arzal and the upstream sites of the two tidal streams were clearly freshwater sites whereas salinity fluctuated a lot from one sampling date to another in the other sites, especially at the outlet of the two tidal streams (Port de Billiers and Kerdavid sampling sites, respectively).

Salinity was significantly lower in 2006 in Le Halguen than in Le Maresclé (Wilcoxon test, $p=0.012$ ) whereas an opposite result was obtained for oxygen saturation, suspended solid and chlorophyll $a$ concentration (Wilcoxon test, $p=$ 0.03, 0.008 and 0.001; respectively). Salinity was significantly lower in 2007 in Les Granges than in Le Maresclé (Wilcoxon test, $p=0.008$ ). No significant differences were shown between these two sites for temperature, oxygen saturation, suspended solid and chlorophyll $a$ concentration (Wilcoxon test, $p=0.55,0.62,0.23$ and 0.74 , respectively). Very high chlorophyll $a$ concentrations were measured on April 18, 2006 in the Vilaine estuary (46 and 109.5 $\mu \mathrm{g} / \mathrm{L}$ in Le Maresclé and Le Halguen, respectively) due to a bloom of the dinoflagellate Heterocapsa triquetra.

Water temperature, salinity, chlorophyll $a$ and suspended solids concentration increased significantly from upstream to downstream in Billiers River and Kerdavid River (Wilcoxon test, $p<0.001$ for all parameters) whereas an opposite trend was observed for oxygen saturation in Billiers River (Wilcoxon test, $p<0.001$ ). No gradient was shown for oxygen saturation in Kerdavid River (Wilcoxon test, $p=0.32$ ).

The two monitoring period were quite contrasted in terms of rainfall and freshwater outflow at Arzal dam. Rainfall was more regularly distributed across the year in 2007 and cumulated rainfall for the April-July period was higher in 2007 than in 2006 (319.4 and $117.6 \mathrm{~mm}$, respectively; Online Resource 1). Patterns of outflow were in agreement with those 
of rainfall (Online Resource 2). Outflow regularly decreased from April to July in 2006 (mean \pm s.e. daily ouflow: 42.8 $\pm 5.1 \mathrm{~m}^{3} / \mathrm{s}$ ) whereas it was slightly higher and more regular in 2007 (mean \pm s.e. daily ouflow: $52.6 \pm 2.0 \mathrm{~m}^{3} / \mathrm{s}$ ). .

\subsection{Concentration of herbicide and biocide residues}

Tables 3 and 4 summarize the results of the residue analysis. Detailed results are provided in Online Resource 5 . Five substances (cyanazine, DCPU, metobromuron, monolinuron and neburon) were never detected.

The highest level of contamination, both in terms of the number of detected compounds and concentration values was observed in Arzal, with 23 detected compounds among which 10 were quantified at least one time (atrazine, DEA, DIA, Irgarol 1051, simazine, diuron, isoproturon, acetochlor, alachlor and metolachlor). The highest peak values were observed for simazine $(2.35 \mu \mathrm{g} / \mathrm{L}$ on May 09,2006$)$ and diuron $(0.268 \mu \mathrm{g} / \mathrm{L}$ on July 24,2006$)$. Atrazine, DEA, Irgarol 1051, simazine, diuron and isoproturon were detected in at least $80 \%$ of the samples, suggesting a chronic exposure to these substances. Atrazine was more frequently quantified in summer and Irgarol 1051 was quantified only in late spring and summer but at relatively high levels. Chloroacetanilides were sometimes detected in 2006 but always at concentrations inferior to the LOQ. Results obtained in 2007 suggest that contamination by these compounds may also exhibit a seasonality with highest concentrations in spring.

The total number of detected compounds was 17 in Le Maresclé (monitoring period: 2006-2007) and Les Granges (monitoring period: 2007), and 8 in Le Halguen (monitoring period: 2006). Diuron was quantified at least once in the three sites but always at concentration levels inferior to $0.1 \mu \mathrm{g} / \mathrm{L}$. These results indicate a much lower level of contamination than in Arzal, with acute rather than chronic exposure to substances transferred from the continent. In Le Maresclé and Le Halguen, the average ratio between the values obtained at low and high tide was 1.12 suggesting a weak influence of dilution by tide. The pattern was different in Les Granges where compounds were usually detected only in samples collected at low tide.

Although numerous compounds were detected in samples from the two tidal streams (from 15 to 21 , depending on the sampling site), few substances were present in quantifiable amounts. DEA was detected in almost all the samples from both streams whereas isoproturon was more frequently detected in Kerdavid River with a maximum value of $1.02 \mu \mathrm{g} / \mathrm{L}$ on May 14, 2007 in the upstream site. Simazine was mainly detected in Billiers River. These results suggest that the exposure to herbicides in these two streams was characterized by pulses of contamination associated with drift phenomena during pesticide application and transfer following rainfall event.

\subsection{Derivation of SSD-based HC5-95\%}

Data were less abundant for saltwater than for freshwater primary producers. Using data for freshwater primary producers only, it was possible to compute EC50-based HC5-95\% for all compounds whereas NOEC-based HC5-95\% 
values could be computed only for atrazine, simazine, Irgarol 1051 and alachlor (Table 5). Due to the low number of available data, EC50-based HC5-95\% values for DEA, acetochlor and metolachlor and NOEC-based HC5-95\% value for isoproturon should be cautiously considered. Ranking of triazine compounds based on their HC5-95\% values for freshwater primary producers was identical for acute and chronic toxicity data, with Irgarol 1051 being more toxic than atrazine, itself more toxic than simazine. The HC5-95\% values for DEA and DIA clearly show that these substances were far less toxic for freshwater primary producers than their mother compound atrazine. EC50-SSDs for phenylureas showed that diuron was more toxic for freshwater primary producers than isoproturon. The values of the slope of the EC50-based SSDs for alachlor and acetochlor were comparable (0.53 and 0.42, respectively) and lower than the value obtained for S-metolachlor (0.89). Values of HC50 estimates suggested that S-metolachlor was more acutely toxic for freshwater primary producers than the two other chloroacetanilides. For alachlor and acetochlor the HC5-95\% values were inferior to 0 due to the high dispersion of the experimental data whereas the confidence interval for S-metolachlor HC was large due to the low number of available data. Therefore, median HC5 values estimates were used instead of the lower limit of their $95 \%$ confidence interval for the assessment of the risk associated with these compounds. Fresh- and saltwater EC50-SSDs for atrazine, diuron and Irgarol 1051 are presented in Figure 2. Confidence intervals of EC50-SSD derived HC5 for fresh- and saltwater primary producers overlapped for Irgarol 1051 and diuron but not for atrazine. The sensitivity distributions were significantly different only for atrazine (Kolmogorov-Smirnov two samples test: $\mathrm{D}=0.371, \mathrm{n} 1=21, \mathrm{n} 2=60, \mathrm{p}=0.027)$. Fresh- and saltwater data were therefore pooled to compute a unique EC50-SSD for diuron and Irgarol 1051 (Table 5). No differences were shown for NOEC-SSD derived HC5 or sensitivity distribution for atrazine and Irgarol 1051. The distributions of NOEC values were not significantly different between fresh- and saltwater species for atrazine, diuron and Irgarol 1051, and unique NOEC-SSDs were therefore computed. Unfortunately, for diuron, the estimate of the HC5-95\% value was inferior to 0 . The median HC5 value estimates was therefore used instead of the lower limit of the $95 \%$ confidence interval for the assessment of the risk associated with this compound.

\subsection{Risk Quotient values}

Diuron and more seasonally Irgarol 1051 exhibited the highest individual RQ values followed by isoproturon (Figure 3a). When diuron and Irgarol 1051 were quantified, the corresponding RQ values were always superior or equal to 1 , with peak values up to more than 100 for Irgarol 1051 in June 2007. Individual RQ values for atrazine and simazine were always inferior to 1 . Due to their very high HC5-95\% values and low concentration in the samples, the RQ values associated with atrazine metabolites were always inferior to $210^{-4}$. Photosystem II inhibitors were responsible for the highest risk for primary producers in Arzal with $\mathrm{RQ}_{\mathrm{m}}$ values superior to 1 from May to July for both years (Figure 3a). In 2007, a very high $R Q_{m}$ value was observed in June $\left(R Q_{m}=113.7\right)$, associated to a peak in Irgarol 1051 concentration 
$\left(R_{\text {Irgarol } 1051}=109.4\right)$. Diuron and Irgarol 1051 accounted on average $( \pm$ s.e. $)$ for $61.5( \pm 8.5) \%$ of the $R Q_{m}$ value when considering the whole dataset. This contribution raised to $83.1( \pm 4.7) \%$ when considering only the dates when their concentrations were above $L O Q$ values. Individual $R Q$ and $\mathrm{RQ}_{\mathrm{m}}$ values computed for chloroacetanilide herbicides were always inferior to 1 suggesting that the risk associated to these compounds for primary producers was very low (Figure 3b).

Since herbicide residues were rarely present at a quantifiable level in saltwater sites, only point estimates of RQ values could be computed. In Le Maresclé, $\mathrm{RQ}_{\mathrm{m}}$ reached 1.84 for photosystem II inhibitors (RQ values of 1.37 and 0.47 for diuron and isoproturon, respectively) at low tide on May 15, 2006. On May 28, 2007 a RQ value of 0.01 was obtained for metolachlor in the same site. In Le Halguen, a maximum value of 1.87 was obtained for $\mathrm{RQ}_{\mathrm{m}}$ computed for photosystem II inhibitors (RQ values of 1.38 and 0.49 for diuron and isoproturon, respectively) at low tide on May 15 , 2006. In Les Granges, a maximum value $R Q_{m}$ value of 1.31 was computed for photosystem II inhibitors $\left(R Q_{i}\right.$ values of 0.01, 0.005 and 1.29 for atrazine, simazine and isoproturon, respectively) at low tide on May 28, 2007. A RQm value of 0.09 was obtained for chloroacetanilide herbicides on the same date and site.

In tidal streams, the highest RQ values were observed in Kervor (Kerdavid River) on May 14, 2007 with a RQ value for isoproturon of 5.1 (concentration: $1.02 \mu \mathrm{g} / \mathrm{L}$ ) and a $\mathrm{RQ}_{\mathrm{m}}$ value of 0.46 for chloroacetanilide herbicides, suggesting a significant risk for primary producers on this date. On the same date, a RQ value of 2.1 was observed for diuron in Kerdavid site. RQ values were slightly lower in the other tidal stream, with maximum values of 0.96 for diuron in Le Marais on June 18, 2007 and 0.14 for acetochlor in Port de Billiers on May 14, 2007.

\section{Discussion}

During this study the lower part Vilaine river was chronically contaminated by a mixture of herbicides and antifouling biocides. The nature of this contamination varied seasonally, and it frequently reached levels of concern for freshwater primary producers in Arzal reservoir. Although its use in agriculture is forbidden in France since 2003, atrazine and its degradation products (DEA, DIA) are still frequently detected in surface waters (SOES, 2011). This is the consequence of the long term transfer of residues from agricultural areas where this herbicide was previously used. Long-lasting contamination of coastal waters by atrazine and its degradation is a commonly reported phenomenon (see e.g., Carafa et al., 1997). During this study, DEA was more frequently detected in freshwater sites than its mother compound, in accordance with the pattern observed at the national level (SOES, 2011). DEA is formed during the degradation of atrazine in soils and it is a stronger leacher than the herbicide (Bottoni et al. 1996). Its presence in surface water showed that atrazine residues were still present in agricultural soils several years after it has been banned. Agricultural use of simazine was also banned in 2003 in France. It is therefore unlikely that the peak concentration recorded in May 2006 in Arzal was the consequence of the former use of this compound. It was more likely the result of an illegal use 
close to Arzal reservoir, for example for eliminating weeds on pavement or other impermeable structures. The concentration rapidly decreased and reached baseline levels in ca. 3 months.

The presence of Irgarol 1051 in water samples from the Arzal reservoir was due to its use in antifouling paints. Irgarol 1051 has been one of the mostly used booster biocide in antifouling paints worldwide and is has frequently been detected in coastal marine environments and lakes, especially close to marinas where its concentrations are frequently higher than in other harbours (Hall et al., 1999; Sánchez-Rodríguez et al. 2011; Hall and Gardinali 2004). This compound has a long half-life in the environment (ca. 200 days in the marine environment) and a high toxicity for aquatic primary producers therefore presenting a great threat to non target organisms (Hall et al. 1999). Maximum measured Irgarol 1051 concentration was $0.186 \mu \mathrm{g} / \mathrm{L}$ which is of the same order of magnitude than concentration values previously reported for marinas by Hall and Gardinali (2004) for the United States $\left(90^{\text {th }}\right.$ percentile of $\left.0.316 \mu \mathrm{g} / \mathrm{L}\right)$ and Sánchez-Rodríguez et al. (2011) for harbours of Gran Canaria island (concentration up to $0.146 \mu \mathrm{g} / \mathrm{L}$ ). The increase of its concentration in late spring and early summer in Arzal was probably due to a seasonal increase of activity within Arzal-Camoël marina, especially cleaning or painting the boat hulls before the beginning of the summer period. A similar seasonal pattern with a peak concentration in summer has been reported in a Swedish marina (KEMI 2006). In a station located in the Scheldt estuary Steen et al. (2001) also showed that Irgarol 1051 concentration started to increase in April and peaked in July..

Isoproturon and diuron are the two phenylureas that were detected and quantified during this study. The former was used intensively for weed control, especially in wheat fields, and it is still authorized for such use. The latter was used as a broad spectrum herbicide and as a booster biocide in antifouling paints. It has been banned for agricultural use in France in 2008 but was still in use when this study was performed. Measured diuron concentrations were slightly higher in the Arzal reservoir (average: $0.088 \mu \mathrm{g} / \mathrm{L}$, range: $<$ LOQ- $0.268 \mu \mathrm{g} / \mathrm{L}$ ) than in the estuarine sites (overall average concentration: $0.039 \mu \mathrm{g} / \mathrm{L}$, range: $<\mathrm{LOQ}-0.075 \mu \mathrm{g} / \mathrm{L}$ ). Similar diuron levels have been reported by Dahl and Blanck (1996) during a study conducted in marinas of the western Swedish coast with concentrations up to $0.1 \mu \mathrm{g} / \mathrm{L}$. In Spanish sites, Ferrer and Barceló (1999) and Sanchez-Rodriguez et al. (2011) recorded concentrations up to $0.2 \mu \mathrm{g} / \mathrm{L}$. In this study, chloroacetanilide herbicides were quantified only in May and June 2007, mostly in Arzal, although acetochlor and metolachlor were also found once in the two tidal streams and in the estuarine sites in May. These results are in accordance with the agricultural use of these substances. Chloroacetanilides are usually applied as pre- or post-emergent herbicides in spring (April to June). Alachlor has been banned in France in June 2008 and acetochlor in December 2011 but both substances were still in use during the study period. S-metolachlor is still authorized for weed control in maize and other crops (e.g., sugarbeet, sunflower, soybean). The absence of quantification for these substances in spring 2006 may be due to the reduced rainfall in the area at this moment. 
Pesticide residue concentrations measured in the sites located in the estuary and Bay of Vilaine were always low and inferior to those measured on the same sampling dates in Arzal, probably because the dam reduced downstream transfer of contaminants. It favoured their retention in the reservoir where degradation may take place and contributes to reduce downstream transfer. This was probably reinforced by a seasonal effect leading to a reduced outflow of freshwater to the estuary during the sampling period. Some compounds exhibited point concentration values at $\mu \mathrm{g} / \mathrm{L}$ level in the two tidal streams. Quantitative information on the water flow associated with these two streams were not available but according to their hydromorphological characteristics (length, width) and to local rainfall data, their contribution to the estuary is probably several order of magnitude lower than the contribution of Vilaine River. Dilution by marine water associated with tidal current is also a major factor of concentration reduction. Le Maresclé sampling site was chosen as a possible reference site for the characterization of the contribution of Vilaine River to the contamination of coastal ecosystems. Residue levels were generally as high in this site as in the sites located within the estuary, especially for phenylureas, suggesting that in fact contamination of the whole area is relatively homogenous. This raises the question of the availability of control sites for monitoring programs. For atrazine and DEA, the results were different since these compounds were never quantified in Le Maresclé. This may be the consequence of dilution by marine waters or of a less conservative dynamics within the marine environment.

The recommended minimum number of data points that should be used for constructing an SSD varies from 10 (Wheeler et al. 2002) to 15-55 depending on the substance and data quality (Newman et al. 2000), although Maltby et al. (2005) used dataset comprising as low as 6 values. This requirement was not met for three EC50-SSDs for freshwater (DEA, acetochlor and S-metolachlor), for one NOEC-SSD for saltwater (Irgarol 1051) and for two NOECSSDs for freshwater primary producers (diuron and isoproturon). Chèvre et al. (2006) proposed to determine HC5-95\% values for compounds with low data availability using a three steps protocol: (1) Derivation of a relative potency $\left(\mathrm{RP}_{i}\right)$ based on the EC50-SSD curves fitted for all substances sharing the same mode of action and using as a reference the compound with the largest dataset; (2) Derivation of the HC5-95\% value from a NOEC-SSD; (3) Prediction of the HC5-95\% value for all the compounds by applying the $\mathrm{RP}_{i}$ values to HC5-95\% value for the reference compound. This method relies on the hypothesis that the EC50-SSDs are parallel for compounds with the same mode of action, that NOEC- and EC-50 SSDs are parallel for each compound and that the RP of each compound is identical for EC50- and NOEC-SSDs. Our estimates of SSD slope showed that at least the two first hypothesis were not verified, preventing us to apply this protocol to our data. However, combining fresh- and saltwater data for some compounds when HC5 estimates and sensitivity distribution were not significantly different enhanced the reliability of HC5-95\% estimates. Our estimates of NOEC-based HC5-95\% are of the same order of magnitude as those proposed by Chèvre et al. (2006) for atrazine (1.2 vs. $1.8 \mu \mathrm{g} / \mathrm{L}$ for this study and Chèvre et al. 2006, respectively), simazine (3.4 vs. $2.8 \mu \mathrm{g} / \mathrm{L}$ for this 
study and Chèvre et al. 2006, respectively) and isoproturon (0.2 vs. $0.3 \mu \mathrm{g} / \mathrm{L}$ for this study and Chèvre et al. 2006, respectively). AA- and MAC-EQS for priority substances and Irgarol 1051 are lower than our estimates of EC50- and NOEC-based HC5-95\%, suggesting that these criteria are more protective for aquatic primary producers. This discrepancy between the two types of values is logical since EQS derivation may take into account other data than acute or chronic toxicity for primary producers, including e.g., toxicity for fish or invertebrates and bioaccumulation aspects. Assessment factors are also used to take into account uncertainty aspects that result in reduced EQS values.

The comparison of EC50-SSDs suggested that saltwater primary producers were more sensitive to acute exposure to atrazine than freshwater species whereas no differences were found for diuron and Irgarol 1051. For chronic toxicity data, no differences were found between the two categories of primary producers for these three compounds. Previous comparison of the sensitivity of fresh- and saltwater organisms to toxicants using SSDs yielded various and sometimes opposite results, depending on the nature of the substances and of the organisms taken into account (Leung et al. 2001; Maltby et al. 2005). However, comparison are lacking for herbicides and available information mainly concern Irgarol 1051. EC50- and NOEC-SSDs have recently been used for deriving AA-EQS and MAC-EQS values for cybutrine, the active ingredient of Irgarol 1051 (Rodriguez Romero 2011). No difference was found between freshwater and saltwater organisms as in our study. HC5 values of 0.129 (confidence interval: 0.069-0.206) and 0.0076 $\mu \mathrm{g} / \mathrm{L}$ (confidence interval : 0.001-0.025) were computed using log-normal based SSDs for acute and chronic toxicity data, respectively. These estimates are almost similar to the results obtained during this study (average values of $0.12 \mathrm{and} 0.0045 \mu \mathrm{g} / \mathrm{L}$ for EC50- and NOEC-based HC5-95\%, respectively). Based on chronic toxicity data, Van Wezel and van Vlaardingen (2004) found that the sensitivities of salt- and freshwater algae to Irgarol 1051 were not statistically different. However their analysis was performed on very small datasets $(n=2$ and 4 for salt- and freshwater algae, respectively). Using their own data and data from the literature, Zhang et al. (2008) showed that EC50-based SSDs of freshwater and saltwater primary producers crossed over each other, suggesting that the relative sensitivities of these two group of species differ at high and low concentrations. They concluded that freshwater autotrophs were more sensitive towards Irgarol 1051. The difference between their findings and the results of the present study is probably due to the fact that we consider a smaller range of EC50 values ( 0.1 to $6.75 \mu \mathrm{g} / \mathrm{L}$ in this study vs. 0.2 to $5,000 \mu \mathrm{g} / \mathrm{L}$ for Zhang et al. 2008).

The comparison of average and maximum concentration values with EQS values listed in Table 1 showed that in Arzal, the mean and maximum concentration values recorded in 2006 and 2007 for Irgarol 1051 exceeded the currently proposed AA- and MAC-EQS values (0.015 and 0.028 vs. $0.0025 \mu \mathrm{g} / \mathrm{L}$ for mean concentration, and 0.034 and 0.186 $\mu \mathrm{g} / \mathrm{L}$ vs. $0.016 \mu \mathrm{g} / \mathrm{L}$ for maximum concentration, respectively). This compound was not quantified in the other sites but 
frequently detected. Since its LOQ $(0.02 \mu \mathrm{g} / \mathrm{L})$ is higher than proposed EQS values it was not possible to conclude. Peak concentration of isoproturon measured in Kervor was slightly higher than the MAC-EQS for this compound (1.02 vs. $1.0 \mu \mathrm{g} / \mathrm{L}$ ). For the other compounds, the mean and maximum concentrations were always lower than the corresponding EQS.

The results obtained for the computation of RQ values allowed to refine the conclusion drawn for the comparison of residue concentration with EQS values in two ways. First, RQ values may be computed for substances for which EQS values are not currently available. Second, the course of RQ values with time gives information on the nature of the risk e.g., acute or chronic. Computed $\mathrm{RQ}_{\mathrm{i}}$ and $\mathrm{RQ}_{\mathrm{m}}$ values were frequently above the threshold level of 1 for samples collected in Arzal, suggesting a chronic risk for freshwater primary producers in this site. Risk was mainly associated with photosystem II inhibitors, and more precisely with diuron and Irgarol 1051. The risk associated with currently used or banned agricultural herbicides was moderate, with individual RQ values usually below 1. In particular, chloracetanilide herbicides did not exhibit a significant risk. When residue concentration values were available, RQ values in the estuarine sites showed a major contribution of diuron. However, individual and cumulative RQ values were usually inferior to 1 in these sites, suggesting a low or even very low risk associated with these compounds for primary producers in the Vilaine estuary. High risk associated with peak RQ values were recorded at the outlet of tidal streams but with probably no consequence for estuarine primary producers due to dilution by marine water associated with tidal current. The retention and degradation of residues upstream of Arzal dam was a another major factor of natural risk reduction. Use of antifouling products was the main source of risk in this area suggesting that the implementation of risk management measures at the level of Arzal-Camoël marina could be the most efficient way to reduce risk. Some measures are already implemented in this marina such as the use of alternative antifouling compounds and dry docks with waste water collection. They should contribute to improve the situation in the forthcoming years.

Comparison of residue concentration with WQC (either HC5-95\% or EQS values) showed that the risk associated with the monitored herbicides was moderate in all sites suggesting that these substances do not exert individually a strong pressure on freshwater and saltwater primary producers. The situation was different for Irgarol 1051 for which high values of RQ were obtained in Arzal, with average and maximum concentration values above the currently proposed AA- and MAC-EQS. The presence of this compound is associated with boating activity in Arzal-Camoël marina. However, the data obtained in estuarine sites suggest that the risk for saltwater primary producers is very low, including for this biocide.

\section{Conclusion}


This study was implemented to obtain information about the transfer of organic micropollutants from continental surface waters to the estuarine environment in the Vilaine River, the major river of NW France. In its lower part Vilaine river is chronically contaminated by a mixture of herbicides and antifouling biocides. The nature of this contamination varies seasonally, and it sometimes reach levels of concern for freshwater primary producers in Arzal reservoir. The highest risk levels were observed for photosystem II inhibitors, especially diuron and Irgarol 1051. The Arzal-Camoël marina located upstream of the Arzal dam was probably the most important contributor to this contamination although compounds of agricultural origin (e.g., isoproturon, chloroacetanilide herbicides) were also present. Although pesticides and booster biocides were sometimes quantified in samples collected in estuarine sites, their concentrations were usually low and the corresponding risk for saltwater primary producers was moderate. The presence of a dam at the upstream part of the estuary clearly reduces downstream transfer of contaminants and the input of contaminants by tidal streams was also very small. It is concluded that although the contaminants taken into account in this study are transferred from the continent to the estuary, their impact on estuarine primary producers is probably moderate.

\section{Acknowledgements}

This program was funded by the French National Research Agency in the framework of the Programme Ecotoxicology and Ecodynamics of Contaminants (ECODYN). The authors wish to thank the personals of the Institution d'Aménagement de la Vilaine for giving access to Arzal dam and to their laboratory facilities. In particular, they gratefully acknowledge V. Véron and L. Audic for providing logistic support to their activities.

\section{References}

AFNOR (1996) Qualité de l'eau - Dosage des matières en suspension - Méthode par filtration sur filtre en fibres de verre, in: AFNOR (Ed.), Qualité de l'eau - $6^{\mathrm{e}}$ édition Tome 2 - Analyses organoleptiques - Mesures Physico-chimiques - Paramètres globaux - Composés organiques. AFNOR, Paris, pp 101-110 Agritox database. http://www.dive.afssa.fr/agritox/php/fiches.php. Accessed 02 May 2012 Ahel M, Evans KM, Fileman TW, Mantoura RFC (1992) Determination of atrazine and simazine in estuarine samples by high-resolution gas chromatography and nitrogen selective detection. Anal Chim Acta 268: 195-204 
Altenburger R, Backhaus T, Boedeker W, Faust M, Scholze M, Grimme LH (2000) Predictability of the toxicity of multiple chemical mixtures to Vibrio fischeri: mixtures composed of similarly acting chemicals. Environ Toxicol Chem 19: 2341-2347

Aminot A, Chaussepied M (1983) Manuel des analyses chimiques en milieu marin. CNEXO, Brest

Aminot A, Kerouel R (2004) Hydrologie des écosystèmes marins: Paramètres et analyses. Editions Quae, Paris Arrhenius A, Grönvall F, Scholze M, Backhaus T, Blanck H (2004) Predictability of the mixture toxicity of 12 similarly acting congeneric inhibitors of photosystem II in marine periphyton and epipsammon communities. Aquat Toxicol 68: 351-367

Babut M, Bonnet C, Bray M, Flammarion P, Garric J, Golaszewski G (2003) Developing environmental quality standards for various pesticides and priority pollutants for French freshwaters. J Environ Manage 69: 139-147

Backhaus T, Altenburger R, Boedeker W, Faust M, Scholze M, Grimme LH (2000) Predictability of the toxicity of multiple mixture of dissimilarly acting chemicals to Vibrio fischeri. Environ Toxicol Chem 19: 2348-2356

Backhaus T, Faust M, Scholze M, Gramatica P, Vighi M, Grimme LH (2004) Joint algal toxicity of phenylurea herbicides is equally predictable by concentration addition and independent action. Environ Toxicol Chem 23: 258-264 Bottoni P, Keizer J, Funari E (1996) Leaching indices of some major triazine metabolites. Chemosphere 32: 1401-1411 Buisson S, Bouchart V, Guerlet E, Malas JP, Costil K (2008) Level of contamination and impact of pesticides in cupped oyster, Crassostrea gigas, reared in a shellfish production area in Normandy (France). J Environ Sci Health B 43: 655664

Carafa R, Wollgast J, Canuti E, Ligthart J, Dueri S, Hanke G, Eisenreich SJ, Viaroli P, Zaldívar JM (2007) Seasonal variations of selected herbicides and related metabolites in water, sediment, seaweed and clams in the Sacca di Goro coastal lagoon (Northern Adriatic). Chemosphere 69: 1625-1637

Chapman PM, Wang F (2001). Assessing sediment contamination in estuaries. Environ Toxicol Chem 20: 3-22 Chesworth JC, Donkin ME, Brown MT (2004) The interactive effects of the antifouling herbicides Irgarol 1051 and diuron on the seagrass Zostera marina (L.). Aquat Toxicol 66: 293-305

Chèvre N, Loepfe C, Singer H, Stamm C, Fenner K, Escher BI (2006) Including mixtures in the determination of water quality criteria for herbicides in surface water. Environ Sci Technol 40: 426-435

Dahl B, Blanck H (1996) Toxic effects of the antifouling agent Irgarol 1051 on periphyton communities in coastal water microcosms. Mar Pollut Bull 32: 342-350 
Di Landa G, Parrella L, Avagliano S, Ansanelli G, Maiello E, Cremisini C (2009) Assessment of the potential ecological risks posed by antifouling booster biocides to the marine ecosystem of the Gulf of Napoli (Italy). Water, Air, Soil Pollut 200: 305-321

Duboudin C, Ciffroy P, Magaud H (2004) Effects of data manipulation and statistical methods on species sensitivity distribution. Environ Toxicol Chem 23: 489-499

ECOTOX (ECOTOXicology) database. http://www.epa.gov/ecotox. Accessed on 30 April 2012

EU (2008) Directive 2008/105/EC of the European Parliament and of the Council of 16 December 2008 on environmental quality standards in the field of water policy, amending and subsequently repealing Council Directives 82/176/EEC, 83/513/EEC, 84/156/EEC, 84/491/EEC, 86/280/EEC and amending Directive 2000/60/EC of the European Parliament and of the Council. Official Journal of the European Union L 384/84. http://eurlex.europa.eu/LexUriServ/LexUriServ.do?uri=OJ:L:2008:348:0084:0097:EN:PDF. Accessed on 30 April 2012

Farcy E, Burgeot Th, Haberkorn H, Auffret M, Lagadic L, Allenou J-P, Budzinski H, Mazzella N, Heydorff M, Menard D, Mondeguer F, Caquet Th. Biomarkers fluctuations in the blue mussel Mytilus edulis L. in the Vilaine estuary, South Brittany, France. Environ Sci Pollut Res, submitted.

Faust M, Altenburger R, Boedecker W, Grimme LH (1994) Algal toxicity of binary combinations of pesticides. Bull Environ Contam Toxicol 53: 134-141

Faust M, Altenburger R, Backhaus T, Blanck H, Boedeker W, Gramatica P, Hamer V, Scholze M, Vighi M, Grimme LH (2001) Predicting the joint algal toxicity of multicomponent s-triazine mixtures at low-effect concentrations of individual toxicants. Aquat Toxicol 56: 13-32

Ferrer I, Barceló D (1999) Simultaneous determination of antifouling herbicides in marina water samples by on-line solid-phase extraction followed by liquid chromatography-mass spectrometry. J Chromatogr A 854: 197-206

Footprint Pesticide Properties DataBase. http://sitem.herts.ac.uk/aeru/footprint/index2.htm. Accessed 02 May 2012

Hall LW, Gardinali P (2004) Ecological risk assessment for Irgarol 1051 and its major metabolite in United States surface waters. Hum Ecol Risk Assess 10: 525-542

Hall LW Jr, Giddings JM, Solomon KR, Balcomb R (1999). An ecological risk assessment for the use of Irgarol 1051 as an algaecide for antifoulant paints. Crit Rev Toxicol 29: 367-437

Haynes D, Muller J, Carter S (2000) Pesticide and herbicide residues in sediments and seagrasses from the great barrier reef world heritage area and Queensland coast. Mar Pollut Bull 41: 279-287.

Johnson LL, Landahl JT, Kubin LA, Horness BH, Myers MS, Collier TK, Stein JE (1998) Assessing the effects of anthropogenic stressors on Puget Sound flatfish populations. J Sea Res 39: 125-137 
Junghans M., Backhaus T, Faust M, Scholze M, Grimme LH (2003) Predictability of combined effects of eight chloroacetanilide herbicides on algal reproduction. Pest Manag Sci 59: 1101-1110

KEMI (2006) Rapport 2/06 Kemiska ämnen i båtbottenfärger - en undersökning av koppar, zink och Irgarol 1051 runt Bullandö marina 2004. http://www.kemi.se/Documents/Publikationer/Trycksaker/Rapporter/Rapport2_06.pdf. Accessed 03 May 2012.

Leung KMY, Morritt D, Wheeler JR, Whitehouse P, Sorokin N, Toy R, Holt M, Crane M (2001) Can saltwater toxicity be predicted from freshwater data? Mar Pollut Bull 42: 1007-1013

Lewis SE, Brodie JE, Bainbridge ZT, Rohde KW, Davis AM, Masters BL, Maughan M, Devlin MJ, Mueller JF, Schaffelke B (2009) Herbicides: A new threat to the Great Barrier Reef. Environ Pollut 157: 2470-2484 Lorenzen CJ (1967) Determination of chlorophyll and pheopigments: Spectrophotometric equations. Limnol Oceanog 12: $343-346$

Maltby L, Blake N, Brock TCM, Van den Brink PJ (2005) Insecticide species sensitivity distributions: importance of test species selection and relevance to aquatic ecosystems. Environ Toxicol Chem 24: 379-388

Mazzella N, Delmas F, Delest B, Méchin B, Madigou C, Allenou JP, Gabellec R, Caquet Th (2009) Investigation of the matrix effects on a HPLC-ESI-MS/MS method and application for monitoring triazine, phenylurea and chloroacetanilide concentrations in fresh and estuarine waters. J Environ Monitor 11: 108-115

Munaron D, Dubernet JF, Delmas F, Stanisiere JY, Scribe P (2006) Assessment of the quantities of herbicides and nutrients brought down by the river Charente to the coast and modelling of the dispersion of atrazine in the MarennesOleron bay. Cah Biol Mar 47: 85-92

Newman MC, Ownby DR, Mézin LCA, Powell DC, Christensen TRL, Lerberg SB, Anderson BA (2000) Applying species-sensitivity distributions in ecological risk assessment: assumptions of distribution type and sufficient numbers of species. Environ Toxicol Chem 19: 508-515

Noppe H, Ghekiere A, Verslycke T, De Wulf E, Verheyden K, Monteyne E, Polfliet K, van Caeter P, Janssen CR, De Brabander HF (2007) Distribution and ecotoxicity of chlorotriazines in the Scheldt Estuary (B-Nl). Environ Pollut 147: $668-676$

Okamura H, Nishida T, Ono Y, Shim WJ (2003) Phytotoxic effects of antifouling compounds on nontarget plant species. Bull Environ Contam Toxicol 71: 881-886

Omae I (2003) Organotin antifouling paints and their alternatives. Appl Organometal Chem 17: 81-105

Owen R, Knap A, Toaspern M, Carbery K (2002) Inhibition of coral photosynthesis by the antifouling herbicide Irgarol 1051. Mar Pollut Bull 44: 623-632 
Power M, Attrill MJ, Thomas RM (1999) Trends in agricultural pesticide (atrazine, lindane, simazine) concentrations in the Thames Estuary. Environ Pollut 104: 31-39

Readman JW, Albanis TA, Barcelo D, Galassi S, Tronczynski J, Gabrielides GP (1993) Herbicide contamination of Mediterranean estuarine waters: results from a MED POL pilot survey. Mar Pollut Bull 26: 613-619

RNO (2004) Surveillance du Milieu Marin. Travaux du RNO. Edition 2004. Ifremer et Ministère de l'Ecologie et du Développement Durable. http://envlit.ifremer.fr/content/download/27644/224815/version/1/file/rno04.pdf. Accessed 01 May 2012

Rodriguez Romero J (2011) Cybutryne EQS dossier 2011. http://circa.europa.eu/Public/irc/env/wfd/library?l= /framework_directive/thematic_documents/priority_substances/supporting_substances/eqs_dossiers/cybutryne_2011pdf /_EN_1.0_\&a=i. Accessed 30 April 2012

Sánchez-Rodríguez A, Sosa-Ferrera Z, Santana-del Pino A, Santana-Rodríguez JJ (2011) Probabilistic risk assessment of common booster biocides in surface waters of the harbours of Gran Canaria (Spain). Mar Pollut Bull 62: 985-991 Shaw M, Müller JF (2005) Preliminary evaluation of the occurrence of herbicides and PAHs in the wet tropics region of the great barrier reef, Australia, using passive samplers. Mar. Pollut Bull 51: 876-881

Smith EP, Cairns J Jr (1993) Extrapolation methods for setting ecological standards for water quality: statistical and ecological concerns. Ecotoxicology 2: 203-219

SOES (2011) Bilan de présence des micropolluants dans les milieux aquatiques continentaux, période 2007-2009. Études \& documents $\quad \mathrm{n}^{\circ} \quad 54 \quad-\quad$ octobre $2011 \quad \mathrm{http}: / / \mathrm{www}$.statistiques.developpementdurable.gouv.fr/fileadmin/documents/Produits_editoriaux/Publications/Etudes_et_documents/2011/E\&D54_p53corrige e_janv2012.pdf. Accessed 30 April 2012

Steen RJCA, van der Vaart J, Hiep M, Van Hattum B, Cofino WP, Brinkman UAT (2001) Gross fluxes and estuarine behaviour of pesticides in the Scheldt Estuary (1995-1997). Environ Pollut 115: 65-79

Van Leeuwen CJ (1990) Ecotoxicological effect assessment in the Netherlands, recent developments. Environ Manag 14: 779-792

Van Wezel AP, van Vlaardingen P (2004). Environmental risk limits for antifouling substances. Aquat. Toxicol. 66: $427-444$

Wheeler JR, Leung KMY, Morritt D, Sorokin N, Roger H, Toy R, Holt M, Whitehouse P, Crane M (2002) Freshwater to saltwater toxicity extrapolation using species sensitivity distributions. Environ Toxicol Chem 21: 2459-2467

Zhang AQ, Leung KMY, Kwok KWH, Bao VWW, Lam MHW (2008) Toxicities of antifouling biocide Irgarol 1051 and its major degraded product to marine primary producers. Mar Pollut Bull 57: 575-586 


\section{Figure captions}

Fig. 1 Map of the study area showing the location of freswhater (white circles), brackishwater (squared circles) and marine water (black circles) sampling sites for pesticide residue analysis. Arrows indicate flow direction

Fig. 2 Species sensitivity distribution curves obtained for atrazine, diuron and Irgarol using EC50 data for freshwater (FW) and saltwater (SW) primary producers

Fig. 3 Change with time of RQ values in Arzal for photosystem II (PSII) inhibitors (a) and elongase inhibitors (b). The horizontal dashed line indicates the threshold above which risk is significant $(\mathrm{RQ}>1)$ 


\section{Online Resource captions}

Online Resource 1 Monthly cumulative rainfall (in mm) recorded in Meteo France station in Theix in 2006 and 2007

Online Resource 2 Daily flow (in $\mathrm{m}^{3} / \mathrm{s}$ ) at the outlet of Arzal dam during the monitoring period in 2006 and 2007

Online Resource 3 Additional information on the analytical methods used for this study.

Online Resource 4 Data used for the construction of the SSDs.

Online Resource 5. Results of the residue analysis for the various compounds analyzed in the water samples collected in the different sampling sites. 
Figure 1

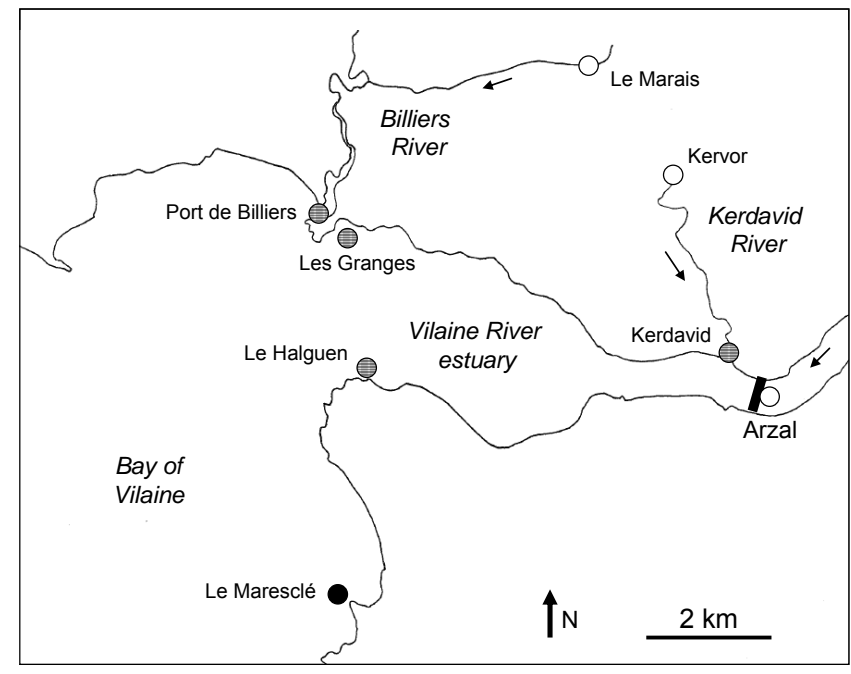




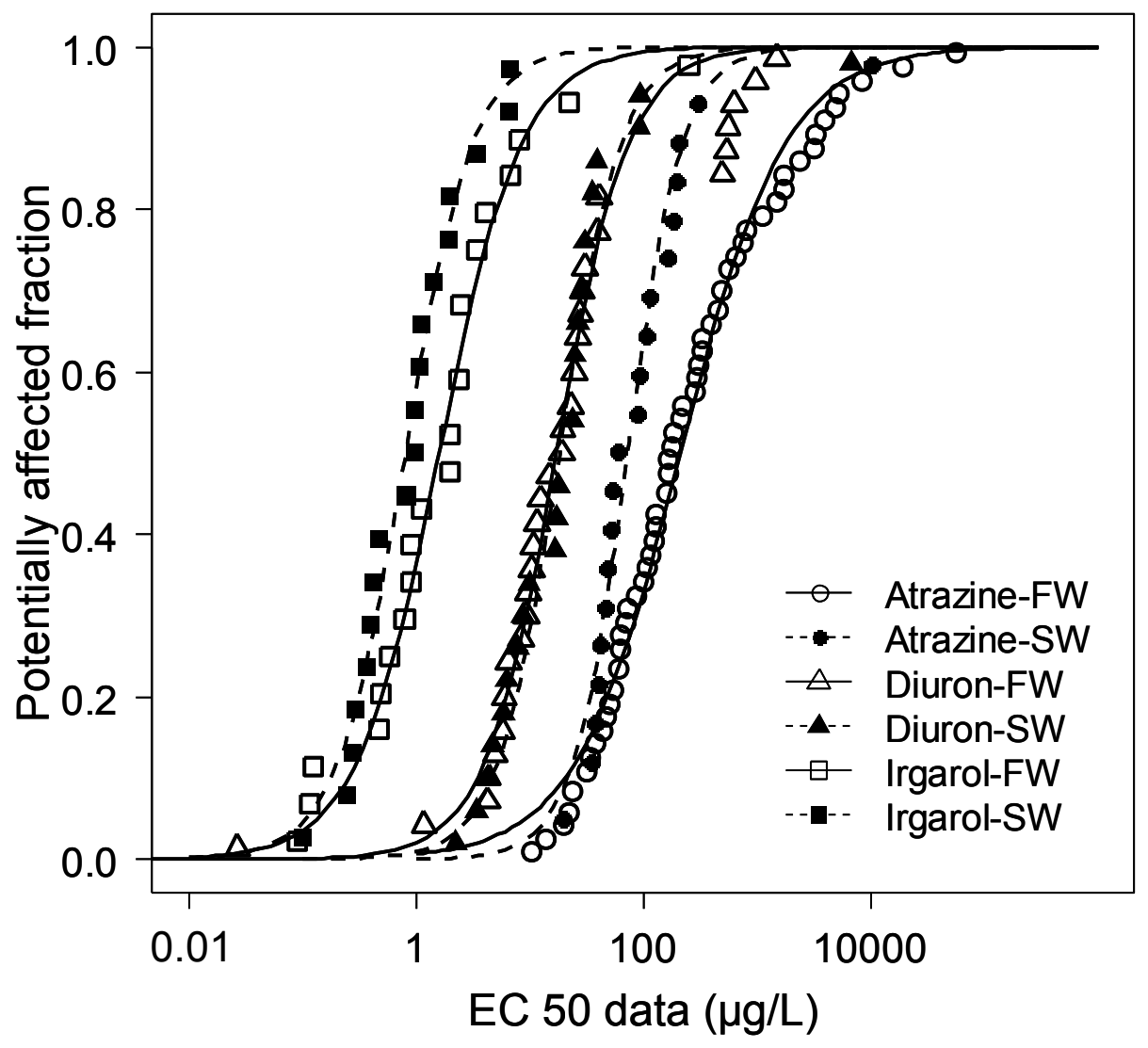


a
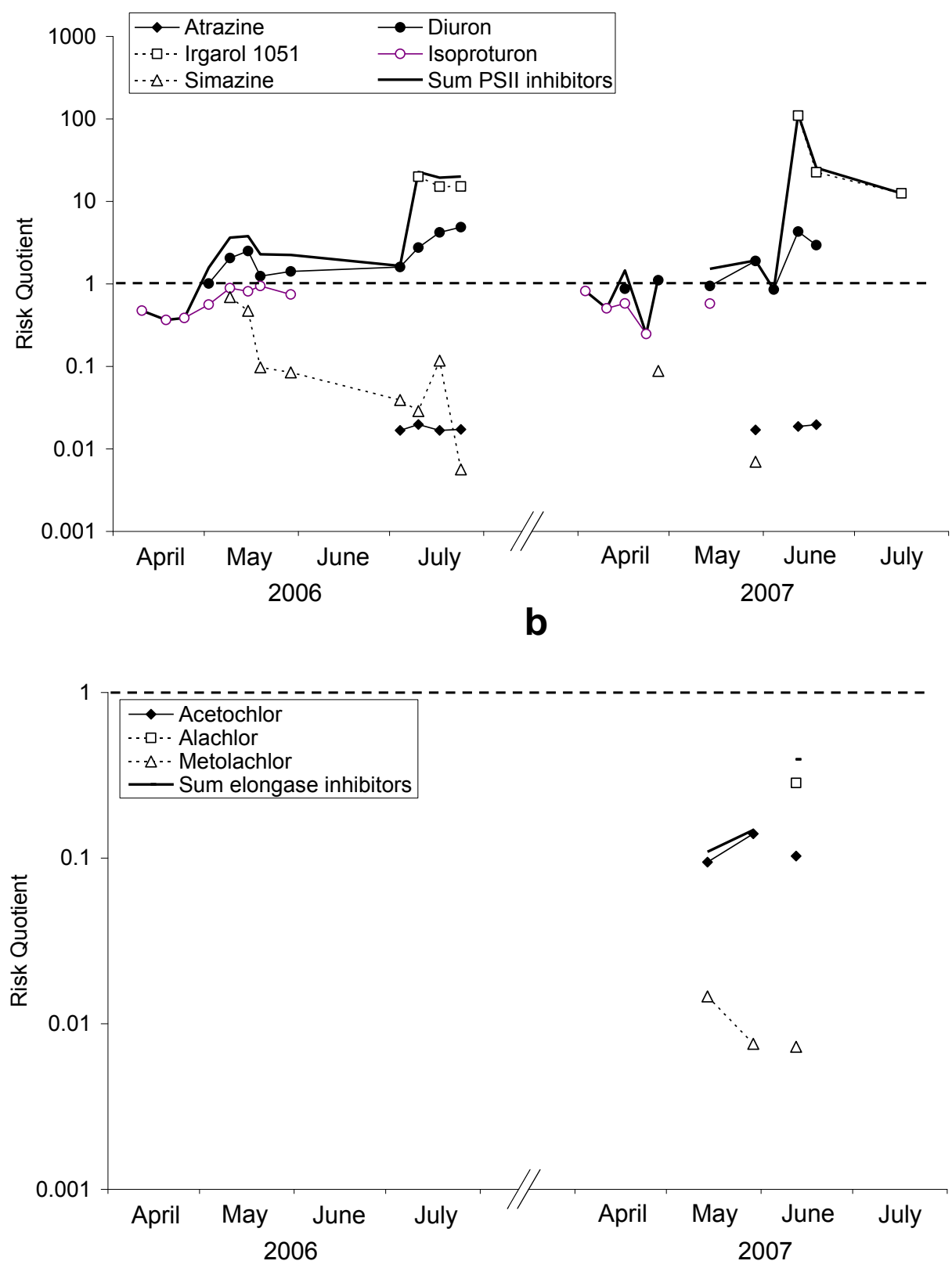
Table 1. Regulatory and proposed EQS values $(\mu \mathrm{g} / \mathrm{L})$ for the substances monitored during the present study (AA: Annual Average; MAC : Maximum Allowable Concentration).

\begin{tabular}{lcc}
\hline \multicolumn{1}{c}{ Substance } & AA-EQS $(\mu \mathrm{g} / \mathrm{L})$ & MAC-EQS $(\mu \mathrm{g} / \mathrm{L})$ \\
\hline Atrazine & $0.3^{\mathrm{a}}$ & $0.7^{\mathrm{a}}$ \\
Simazine & $1.0^{\mathrm{a}}$ & $4.0^{\mathrm{a}}$ \\
Diuron & $0.2^{\mathrm{a}}$ & $1.8^{\mathrm{a}}$ \\
Isoproturon & $0.3^{\mathrm{a}}$ & $1.0^{\mathrm{a}}$ \\
Alachlor & $0.3^{\mathrm{a}}$ & $0.7^{\mathrm{a}}$ \\
Irgarol 1051 & $0.0025^{\mathrm{b}}$ & $0.016^{\mathrm{b}}$ \\
\hline${ }^{\mathrm{a}}$ Regulatory value & \\
${ }^{\mathrm{b}}$ Proposed value (Rodriguez Romero 2011)
\end{tabular}


Table 2. Mean, standard error and range of variation for the various water physico-chemical parameters measured in the different sampling sites

\begin{tabular}{|c|c|c|c|c|c|}
\hline Sampling site & $\begin{array}{c}\text { Temperature } \\
\left({ }^{\circ} \mathrm{C}\right)\end{array}$ & $\begin{array}{l}\text { Salinity } \\
(\%)\end{array}$ & $\begin{array}{c}\text { Oxygen saturation } \\
(\%)\end{array}$ & $\begin{array}{c}{[\text { Chlorophyll } a]} \\
(\mu \mathrm{g} / \mathrm{L})\end{array}$ & $\begin{array}{c}\text { [Suspended solids] } \\
(\mathrm{mg} / \mathrm{L})\end{array}$ \\
\hline \multirow[t]{2}{*}{ Arzal } & $19.4(1.0)$ & 0 & $91.7(2.9)$ & $5.5(1.1)$ & $7.5(1.1)$ \\
\hline & {$[12.1-25.3]$} & & {$[79-118.5]$} & {$[0.6-14.4]$} & {$[4.0-17.4]$} \\
\hline \multirow[t]{2}{*}{ Le Marais } & $15.0(0.7)$ & 0 & $92.7(0.6)$ & $3.4(0.4)$ & $7.0(0.7)$ \\
\hline & {$[10.3-18.0]$} & & {$[89.9-96.6]$} & {$[1.3-5.8]$} & {$[3.6-10.9]$} \\
\hline \multirow[t]{2}{*}{ Port de Billiers } & $18.9(0.7)$ & $6.1(1.8)$ & $79.2(1.3)$ & $23.2(2.0)$ & $121.6(38.3)$ \\
\hline & {$[15.5-21.9]$} & {$[1.0-20.0]$} & [70.9-85.9] & {$[11.9-34.2]$} & {$[21.4-528.3]$} \\
\hline \multirow[t]{2}{*}{ Kervor } & $15.6(0.6)$ & 0 & $83.4(1.6)$ & $2.0(0.5)$ & $9.7(2.3)$ \\
\hline & {$[11.5-18.0]$} & & {$[71.7-89.2]$} & {$[0.8-5.6]$} & {$[3.3-31.7]$} \\
\hline \multirow[t]{2}{*}{ Kerdavid } & $18.6(1.2)$ & $1.6(0.5)$ & $78.2(8.9)$ & $11.0(6.0)$ & $25.4(10.0)$ \\
\hline & {$[13.9-23.7]$} & {$[0-4.1]$} & {$[53.5-132.4]$} & {$[4.0-53.9]$} & {$[7.5-96.6]$} \\
\hline \multicolumn{6}{|l|}{ Le Maresclé } \\
\hline \multirow[t]{2}{*}{2006} & $17.6(0.9)$ & $31.5(0.4)$ & $119.3(5.7)$ & $15.1(9.8)$ & $4.9(0.6)$ \\
\hline & {$[12.0-22.2]$} & {$[28.1-33.6]$} & [94.0-144] & {$[1.8-83.6]$} & {$[0.3-8.3]$} \\
\hline \multirow[t]{2}{*}{2007} & $17.4(0.8)$ & $32.2(0.4)$ & $109.3(3.3)$ & $20.6(10.0)$ & $26.7(10.0)$ \\
\hline & {$[14.5-20.4]$} & {$[30.7-34]$} & [99.0-122.0] & {$[2.8-85.9]$} & {$[3.6-84.6]$} \\
\hline \multirow[t]{2}{*}{ Le Halguen } & $17.8(0.9)$ & $30.9(0.6)$ & $124.7(6.3)$ & $34.2(23.6)$ & $9.2(1.2)$ \\
\hline & {$[12.0-22.8]$} & [26.8-34.0] & [94.5-147.3] & [2.7-199.1] & {$[3.5-18.7]$} \\
\hline \multirow[t]{2}{*}{ Les Granges } & $17.5(0.7)$ & $30.2(0.9)$ & $107.6(4.5)$ & $14.4(2.2)$ & $36.6(6.9)$ \\
\hline & [14.9-20.1] & {$[25.5-33.1]$} & {$[86.0-130]$} & {$[9.0-27.6]$} & [14.9-66.8] \\
\hline
\end{tabular}




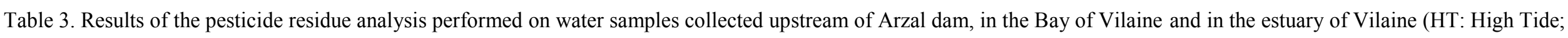

LT: Low Tide; N: number of samples; LOQ: limit of quantification; -: not detected). Concentration values are expressed in $\mu \mathrm{g} / \mathrm{L}$.

\begin{tabular}{|c|c|c|c|c|c|c|c|}
\hline \multirow[t]{2}{*}{ Substance } & \multirow{2}{*}{$\begin{array}{l}\text { Arzal } \\
(\mathrm{N}=24)\end{array}$} & \multicolumn{2}{|c|}{ Le Maresclé } & \multicolumn{2}{|c|}{ Le Halguen } & \multicolumn{2}{|c|}{ Les Granges } \\
\hline & & LT $(\mathrm{N}=10)$ & HT $(\mathrm{N}=8)$ & $\mathrm{LT}(\mathrm{N}=2)$ & $\mathrm{HT}(\mathrm{N}=2)$ & $\mathrm{LT}(\mathrm{N}=8)$ & $\mathrm{HT}(\mathrm{N}=6)$ \\
\hline Ametryn & $0.75 / 0^{\mathrm{a}}$ & $0.3 / 0$ & $0.4 / 0$ & $1.0 / 0$ & $1.0 / 0$ & $0.125 / 0$ & $0.167 / 0$ \\
\hline Atrazine & $\begin{array}{c}0.67 / 0.29 ; 0.014^{\mathrm{b}} \\
{[<\mathrm{LOQ}-0.32]^{\mathrm{c}}}\end{array}$ & $0.4 / 0$ & $0.625 / 0$ & $1.0 / 0$ & $1.0 / 0$ & $\begin{array}{c}0.375 / 0.125 ; 0.012 \\
{[<\text { LOQ- } 0.02]}\end{array}$ & $0.5 / 0$ \\
\hline DEA & $\begin{array}{c}0.46 / 0.54 ; 0.017 \\
{[<\text { LOQ-0.055] }}\end{array}$ & $0.5 / 0$ & $0.5 / 0$ & $0.5 / 0$ & $0.5 / 0$ & $\begin{array}{c}0.625 / 0.375 ; 0.013 \\
{[<\text { LOQ- } 0.02]}\end{array}$ & $1.0 / 0$ \\
\hline DET & $0.38 / 0$ & $0.1 / 0$ & $0.25 / 0$ & $0.5 / 0$ & - & $0.375 / 0$ & $0.5 / 0$ \\
\hline DIA & $\begin{array}{c}0.25 / 0.04 ; 0.012 \\
{[<\mathrm{LOQ}-0.032]}\end{array}$ & $0.1 / 0$ & $0.125 / 0$ & - & - & $0.25 / 0$ & - \\
\hline Irgarol 1051 & $\begin{array}{c}0.71 / 0.24 ; 0.014 \\
{[<\text { LOQ-0.186] }}\end{array}$ & $0.7 / 0$ & $0.5 / 0$ & $1.0 / 0$ & $1.0 / 0$ & $0.875 / 0$ & $0.67 / 0$ \\
\hline Prometryn & $0.21 / 0$ & $0.1 / 0$ & $0.125 / 0$ & - & - & $0.125 / 0$ & $0.33 / 0$ \\
\hline Simazine & $\begin{array}{c}0.38 / 0.42 ; 0.296 \\
{[<\mathrm{LOQ}-2.352]}\end{array}$ & $0.2 / 0$ & $0.375 / 0$ & $0.5 / 0$ & $0.5 / 0$ & $\begin{array}{c}0.5 / 0.25 ; 0.013 \\
{[<\mathrm{LOQ}-0.02]}\end{array}$ & $0.5 / 0$ \\
\hline Terbuthylazine & $0.67 / 0$ & $0.2 / 0$ & $0.25 / 0$ & $0.5 / 0$ & $0.5 / 0$ & $0.125 / 0$ & $0.167 / 0$ \\
\hline Terbutryn & $0.67 / 0$ & $0.2 / 0$ & $0.125 / 0$ & - & - & $0.625 / 0$ & $0.667 / 0$ \\
\hline Chlortoluron & $0.29 / 0$ & - & $0.125 / 0$ & - & - & $0.125 / 0$ & $0.33 / 0$ \\
\hline Diuron & $\begin{array}{c}0.33 / 0.67 ; 0.088 \\
{[<\text { LOQ-0.268] }}\end{array}$ & $\begin{array}{c}0.4 / 0.1 ; 0.035 \\
{[<\text { LOQ- } 0.075]}\end{array}$ & $\begin{array}{c}0.375 / 0.125 ; 0.033 \\
{[<\text { LOQ- } 0.056]}\end{array}$ & $\begin{array}{c}0.5 / 0.5 ; 0.05 \\
{[<\text { LOQ- } 0.076]}\end{array}$ & $\begin{array}{l}0.5 / 0.5 ; 0.048 \\
{[<\text { LOQ- } 0.071]}\end{array}$ & $\begin{array}{c}0.625 / 0.25 ; 0.035 \\
{[<\text { LOQ-0.071] }}\end{array}$ & $0.5 / 0$ \\
\hline DCPMU & $0.08 / 0$ & - & - & - & - & - & - \\
\hline Fenuron & $0.125 / 0$ & $0.1 / 0$ & $0.125 / 0$ & - & - & $0.25 / 0$ & $0.33 / 0$ \\
\hline Isoproturon & $\begin{array}{c}0.33 / 0.54 ; 0.085 \\
{[<\text { LOQ-0.188] }}\end{array}$ & $\begin{array}{l}0.5 / 0.1 ; 0.036 \\
{[<\text { LOQ-0.094] }}\end{array}$ & $\begin{array}{c}0.625 / 0.125 ; 0.036 \\
\quad[<\text { LOQ-0.088] }\end{array}$ & $\begin{array}{l}0.5 / 0.5 ; 0.061 \\
{[<\text { LOQ-0.097] }}\end{array}$ & $\begin{array}{c}0.5 / 0.5 ; 0.06 \\
{[<\text { LOQ-0.096] }}\end{array}$ & $0.625 / 0$ & $0.5 / 0$ \\
\hline IPPMU & $0.53 / 0$ & $0.1 / 0$ & $0.125 / 0$ & - & - & $0.25 / 0$ & $0.167 / 0$ \\
\hline
\end{tabular}




\begin{tabular}{|c|c|c|c|c|c|c|c|}
\hline IPPU & $0.08 / 0$ & - & - & - & - & - & - \\
\hline Linuron & - & - & $0.125 / 0$ & - & - & - & $0.167 / 0$ \\
\hline Metoxuron & $0.17 / 0$ & - & - & - & - & - & \\
\hline Monuron & $0.17 / 0$ & $0.1 / 0$ & $0.125 / 0$ & $0.5 / 0$ & $0.5 / 0$ & $0.125 / 0$ & $0.167 / 0$ \\
\hline Acetochlor & $\begin{array}{c}0.13 / 0.13 ; 0.055 \\
{[<\text { LOQ-0.105] }}\end{array}$ & - & - & - & - & $\begin{array}{c}0.125 / 0 / 125 ; 0.048 \\
\quad[<\text { LOQ-0.071] }\end{array}$ & $0.167 / 0$ \\
\hline Alachlor & $\begin{array}{c}0.04 / 0.04 ; 0.041 \\
{[<\text { LOQ-0.057] }}\end{array}$ & - & - & - & - & $0.125 / 0$ & - \\
\hline Metolachlor & $\begin{array}{c}0.375 / 0.125 ; 0.034 \\
\quad[<\text { LOQ-0.094] }\end{array}$ & $\begin{array}{c}0.3 / 0.1 ; 0.036 \\
{[<\text { LOQ- } 0.068]}\end{array}$ & $0.25 / 0$ & - & - & $0.5 / 0$ & $0.33 / 0$ \\
\hline Metazachlor & & $0.08 / 0$ & $0.125 / 0$ & - & - & $0.25 / 0$ & $0.33 / 0$ \\
\hline
\end{tabular}

${ }^{\text {a }}$ Percentage of samples with residue concentration $<\mathrm{LOQ} /$ percentage of samples with residue concentration $>$ LOQ.

${ }^{\mathrm{b}}$ Arithmetic mean (computed using LOQ/2 when residues were detected but that quantification was not possible).

${ }^{\mathrm{c}}$ Range of concentration values. 
Table 4. Results of the pesticide residue analysis performed on water samples collected in Kerdavid and Billiers River (N: number of samples; LOQ: limit of quantification; -: not detected). Concentration values are expressed in $\mu \mathrm{g} / \mathrm{L}$.

\begin{tabular}{|c|c|c|c|c|}
\hline Substance & Kervor $(\mathrm{N}=9)$ & Kerdavid $(\mathrm{N}=9)$ & Le Marais $(\mathrm{N}=9)$ & Port de Billiers $(\mathrm{N}=9)$ \\
\hline Ametryn & $0.22 / 0^{\mathrm{a}}$ & $0.22 / 0$ & $0.11 / 0$ & $0.11 / 0$ \\
\hline Atrazine & $0.44 / 0$ & $\begin{array}{c}0.44 / 0.11 ; 0.012 \\
{[<\text { LOQ- } 0.02]}\end{array}$ & $0.44 / 0$ & $0.44 / 0$ \\
\hline Cyanazine & $0.11 / 0$ & $0.11 / 0$ & $0.11 / 0$ & $0.11 / 0$ \\
\hline DEA & $\begin{array}{c}0.78 / 0.22 ; 0.012^{\mathrm{b}} \\
\quad[<\mathrm{LOQ}-0.02]^{\mathrm{c}}\end{array}$ & $\begin{array}{c}0.89 / 0.11 ; 0.011 \\
{[<\text { LOQ- } 0.02]}\end{array}$ & $\begin{array}{c}0.55 / 0.45 ; 0.014 \\
{[<\text { LOQ- } 0.02]}\end{array}$ & $\begin{array}{c}0.22 / 0.67 ; 0.022 \\
{[<\text { LOQ-0.065] }}\end{array}$ \\
\hline DET & $0.55 / 0$ & $0.44 / 0$ & $0.33 / 0$ & $0.33 / 0$ \\
\hline DIA & $0.33 / 0$ & $0.11 / 0$ & $\begin{array}{c}0.55 / 0.11 ; 0.011 \\
{[<\text { LOQ- } 0.02]}\end{array}$ & $\begin{array}{c}0.22 / 0.11 .0 .017 \\
{[<\text { LOQ-0.03] }}\end{array}$ \\
\hline Irgarol 1051 & $0.44 / 0$ & $0.44 / 0$ & $0.11 / 0$ & $0.78 / 0$ \\
\hline Prometryn & $0.44 / 0$ & $0.33 / 0$ & $0.11 / 0$ & $0.22 / 0$ \\
\hline Propazine & $0.44 / 0$ & $0.22 / 0$ & $0.22 / 0$ & $0.22 / 0$ \\
\hline Simazine & $0.55 / 0$ & $0.44 / 0$ & $\begin{array}{c}0.67 / 0.22 ; 0.013 \\
{[<\text { LOQ- } 0.02]}\end{array}$ & $\begin{array}{c}0.44 / 0.11 .0 .012 \\
{[<\text { LOQ-0.02] }}\end{array}$ \\
\hline Terbuthylazine & $0.22 / 0$ & $0.22 / 0$ & $0.22 / 0$ & $0.11 / 0$ \\
\hline Terbutryn & $0.33 / 0$ & $0.44 / 0$ & $0.33 / 0$ & $0.78 / 0$ \\
\hline Chlortoluron & $0.11 / 0$ & $0.22 / 0$ & - & $0.22 / 0$ \\
\hline Diuron & $0.44 / 0$ & $\begin{array}{c}0.33 / 0.11 ; 0.047 \\
{[<\text { LOQ-0.115] }}\end{array}$ & $\begin{array}{c}0.44 / 0.11 ; 0.031 \\
{[<\text { LOQ- } 0.05]}\end{array}$ & $0.78 / 0$ \\
\hline DCPMU & $0.11 / 0$ & $0.11 / 0$ & - & $0.11 / 0$ \\
\hline Fenuron & $0.22 / 0$ & $0.22 / 0$ & $0.22 / 0$ & $0.22 / 0$ \\
\hline Isoproturon & $\begin{array}{c}0.33 / 0.22 ; 0.228 \\
{[<\text { LOQ- } 1.02]}\end{array}$ & $\begin{array}{c}0.44 / 0.11 ; 0.03 \\
{[<\text { LOQ- }-0.05]}\end{array}$ & $0.67 / 0$ & $0.67 / 0$ \\
\hline IPPMU & $0.22 / 0$ & $0.22 / 0$ & $0.22 / 0$ & $0.22 / 0$ \\
\hline IPPU & $0.11 / 0$ & $0.11 / 0$ & - & - \\
\hline Linuron & - & $0.11 / 0$ & - & - \\
\hline Metoxuron & $0.11 / 0$ & $0.22 / 0$ & - & $0.22 / 0$ \\
\hline Monuron & $0.11 / 0$ & - & - & - \\
\hline Neburon & $0.11 / 0$ & $0.11 / 0$ & - & - \\
\hline Acetochlor & $0 / 0.11 ; 0.289$ & $0.11 / 0$ & $0.11 / 0$ & $\begin{array}{l}0.22 / 0.11 ; 0.06 \\
{[<\text { LOQ-0.102] }}\end{array}$ \\
\hline Metolachlor & $\begin{array}{c}0.55 / 0.11 ; 0.104 \\
{[<\text { LOQ- } 0.500]}\end{array}$ & $0.44 / 0$ & $0.33 / 0$ & $0.33 / 0$ \\
\hline Metazachlor & $0.33 / 0$ & - & $0.22 / 0$ & $0.22 / 0$ \\
\hline
\end{tabular}

\footnotetext{
${ }^{a}$ Percentage of samples with residue concentration $<\mathrm{LOQ} /$ percentage of samples with residue concentration $>$ LOQ.

${ }^{\mathrm{b}}$ Arithmetic mean (computed using LOQ/2 when residues were detected but that quantification was not possible).

${ }^{\mathrm{c}}$ Range of concentration values.
} 
Table 5. Slope (standard error) of the SSD, mean HC50 and HC5 values and their 95\% confidence intervals (between brackets) for fresh- and saltwater primary producers estimated from EC50- and NOEC-SSDs for different triazines, phenylureas and chloroacetanilides. Values in italics have been computed with less than 10 data and should therefore be only considered as indicative (FW: freshwater; SW: saltwater; N: number of data points ; NC: not computed).

\begin{tabular}{|c|c|c|c|c|c|c|}
\hline Compound & Media & Data & $\mathrm{N}$ & $\begin{array}{c}\text { Slope of the } \\
\text { SSD curve } \\
\text { (standard error) }\end{array}$ & $\mathrm{HC} 50(\mu \mathrm{g} / \mathrm{L})$ & $\mathrm{HC} 5(\mu \mathrm{g} / \mathrm{L})$ \\
\hline \multirow[t]{5}{*}{ Atrazine } & $\mathrm{FW}$ & EC50 & 60 & $0.94(0.02)$ & $213.6[204.7-222.4]$ & 9.3. [8.1-10.4] \\
\hline & & NOEC & 42 & $1.21(0.12)$ & $21.2[19.2-23.2]$ & $1.8[1.2-2.5]$ \\
\hline & SW & EC50 & 21 & $1.79(0.11)$ & $73.4[68.3-78.4]$ & $14.2[11.7-16.6]$ \\
\hline & & NOEC & 17 & $1.26(0.12)$ & $22.6[19.7-25.5]$ & $2.2[1.3-3.1]$ \\
\hline & $\mathrm{FW}+\mathrm{SW}$ & NOEC & 59 & $1.21(0.06)$ & $22.7[21.4-24.0]$ & $2.0[1.6-2.4]$ \\
\hline DEA & FW & EC50 & 9 & $2.21(0.18)$ & 920.0 [854-987] & 243.0 [192-293] \\
\hline DIA & FW & EC50 & 13 & $1.97(0.18)$ & $3084.0[2754-3414]$ & $690.4[507-873]$ \\
\hline \multirow[t]{6}{*}{ Irgarol 1051} & FW & EC50 & 22 & $1.19(0.07)$ & $1.6[1.5-1.7]$ & $0.13[0.10-0.17]$ \\
\hline & & NOEC & 8 & $0.73(0.06)$ & $0.27[0.23-0.32]$ & $0.005[0.002-0.008]$ \\
\hline & SW & EC50 & 19 & $1.47(0.09)$ & $0.8[0.74-0.87]$ & $0.11[0.08-0.13]$ \\
\hline & & NOEC & 12 & $0.50(0.03)$ & $1.4[1.1-1.6]$ & $0.004[0.001-0.006]$ \\
\hline & $\mathrm{FW}+\mathrm{SW}$ & EC50 & 41 & $1.25(0.028)$ & $1.14[1.11-1.17]$ & $0.108[0.098-0.118]$ \\
\hline & & NOEC & 20 & $0.57(0.03)$ & $0.62[0.53-0.70]$ & $0.0037[0.0017-0.0056]$ \\
\hline \multirow[t]{4}{*}{ Simazine } & FW & EC50 & 25 & $1.08(0.06)$ & $202.5[187.4-217.5]$ & $13.4[10.0-16.8]$ \\
\hline & & NOEC & 12 & $1.58(0.26)$ & $50.7[42.8-58.5]$ & $7.9[3.4-12.5]$ \\
\hline & SW & EC50 & 1 & $\mathrm{NC}$ & $\mathrm{NC}$ & $\mathrm{NC}$ \\
\hline & & NOEC & 3 & $\mathrm{NC}$ & $\mathrm{NC}$ & $\mathrm{NC}$ \\
\hline \multirow[t]{6}{*}{ Diuron } & $\mathrm{FW}$ & EC50 & 35 & $1.37(0.08)$ & $17.3[16.2-18.4]$ & $2.0[1.6-2.4]$ \\
\hline & & NOEC & 5 & $\mathrm{NC}$ & $\mathrm{NC}$ & $\mathrm{NC}$ \\
\hline & SW & EC50 & 25 & $1.60(0.13)$ & $18.3[7.0-19.7]$ & $2.9[2.1-3.7]$ \\
\hline & & NOEC & 8 & $1.72(0.35)$ & $1.5[1.2-1.7]$ & $0.26[0.06-0.47]$ \\
\hline & $\mathrm{FW}+\mathrm{SW}$ & EC50 & 60 & $1.43(0.05)$ & $17.6[16.9-18.2]$ & $2.3[2.0-2.6]$ \\
\hline & & NOEC & 13 & $1.07(0.18)$ & $0.86[0.61-1.1]$ & $0.055[-0.0003-0.11]$ \\
\hline \multirow[t]{4}{*}{ Isoproturon } & FW & EC50 & 12 & $2.61(0.157)$ & $35.0[33.7-36.2]$ & $11.3[9.9-12.8]$ \\
\hline & & NOEC & 7 & $1.29(0.202)$ & $10.2[7.4-13.1]$ & $1.0[0.2-1.9]$ \\
\hline & SW & EC50 & 4 & $\mathrm{NC}$ & $\mathrm{NC}$ & $\mathrm{NC}$ \\
\hline & & NOEC & 2 & $\mathrm{NC}$ & $\mathrm{NC}$ & $\mathrm{NC}$ \\
\hline Acetochlor & FW & EC50 & 9 & $0.42(0.08)$ & 825.2 [125.7-1524.7] & $0.75[-1.6-3.1]$ \\
\hline \multirow[t]{4}{*}{ Alachlor } & $\mathrm{FW}$ & EC50 & 26 & $0.53(0.04)$ & $699.2[505.2-893.1]$ & $2.7[0.2-5.2]$ \\
\hline & & NOEC & 14 & $0.737(0.06)$ & $156.5[130.7-182.3]$ & $2.9[1.0-4.8]$ \\
\hline & SW & EC50 & 2 & $\mathrm{NC}$ & $\mathrm{NC}$ & $\mathrm{NC}$ \\
\hline & & NOEC & 2 & $\mathrm{NC}$ & $\mathrm{NC}$ & $\mathrm{NC}$ \\
\hline S-metolachlor & FW & EC50 & 6 & $0.89(0.14)$ & $174.4[122.4-226.3]$ & $6.4[-0.7-13.5]$ \\
\hline
\end{tabular}


Supplementary Material 1
Click here to download Supplementary Material: ESM_1.pdf

ck here to download Supplementary Material: ESM_1.pdf

$+2$

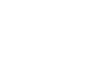

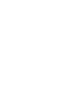

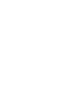

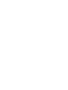
(

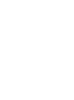
.

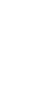
. . (1) (1) (1) (1) (1) (1) (1) (1) (1) (1) (1) (1) (1) (1)

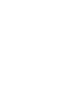

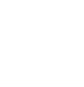

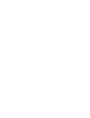

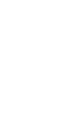

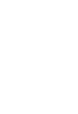

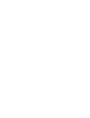

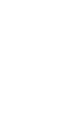

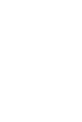

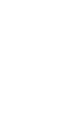

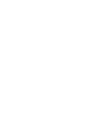

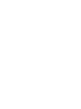

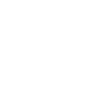

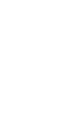

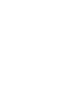

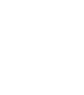

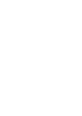

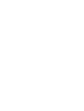

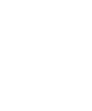

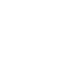

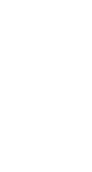
更

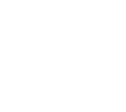

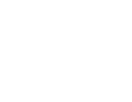

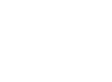

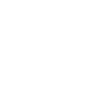

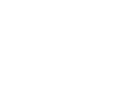

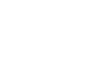

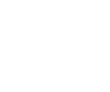

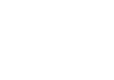

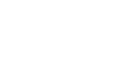

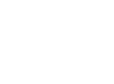
r

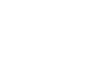
. . 
Supplementary Material 2
Click here to download Supplementary Material: ESM_2.pdf

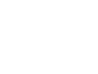

(1)
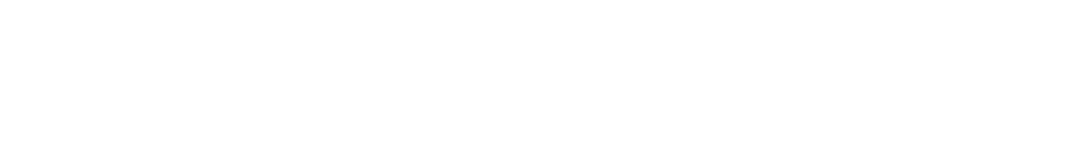
Supplementary Material 3
Click here to download Supplementary Material: ESM_3.pdf

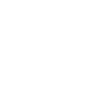

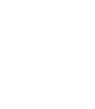

(

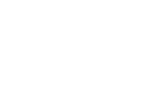

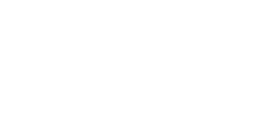




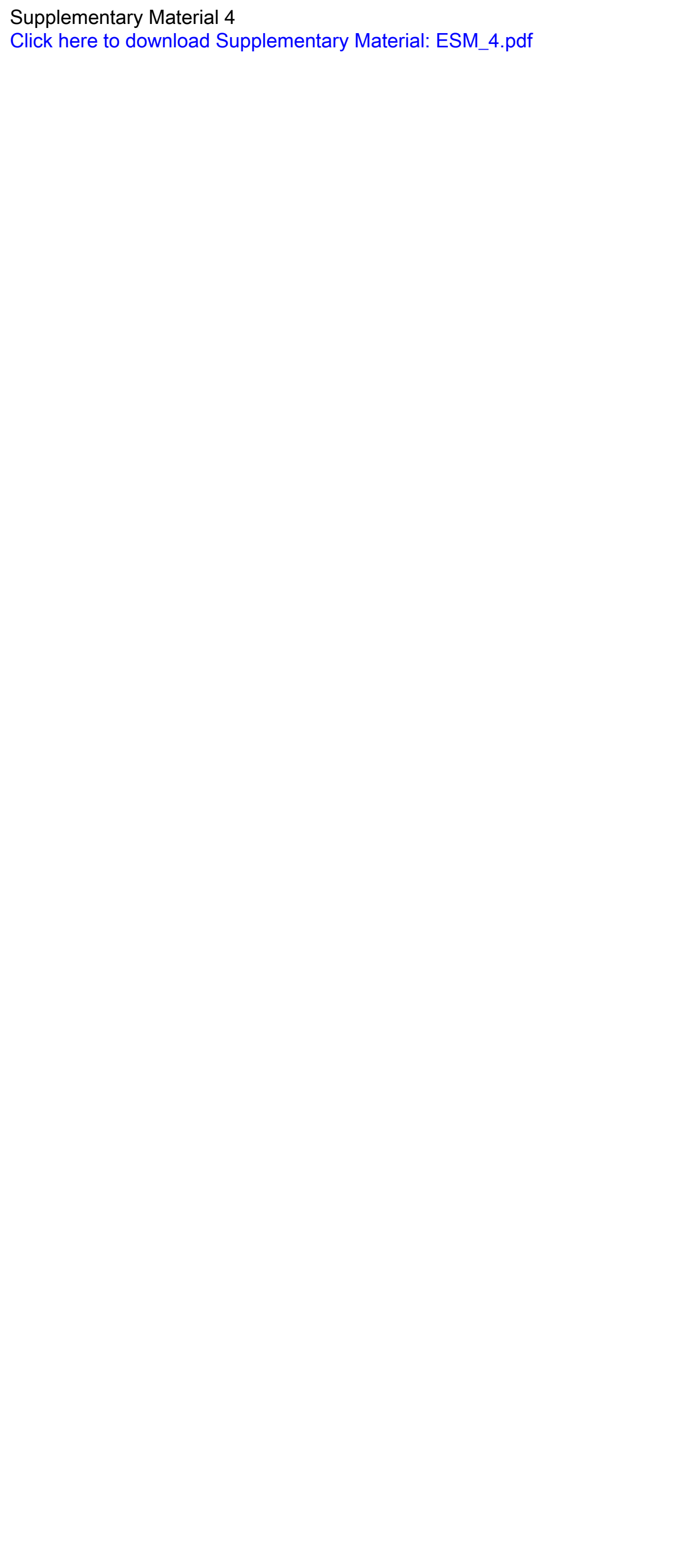

每

Supplementary Material 4 Sick here to download Supplementary Material: ESM_4.pdf
Cli Supplementary Material 4
Click here to download Supplementary Material: ESM__.pdf

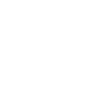

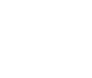

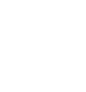

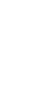

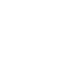

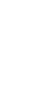
.

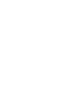

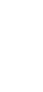
.

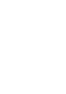

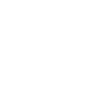

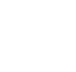

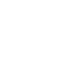

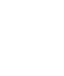

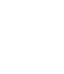

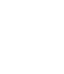

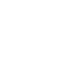

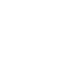

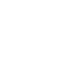

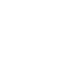

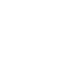
更

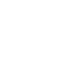

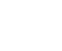


Supplementary Material 5
Click here to download Supplementary Material: ESM_5.pdf

$(2+2$

ches

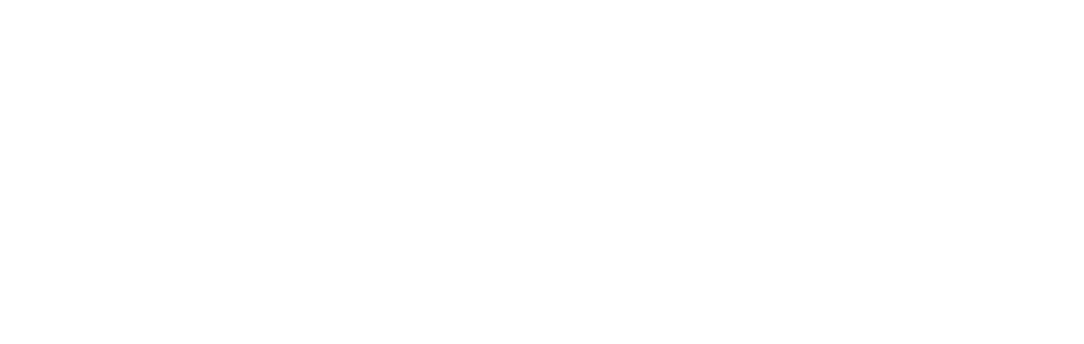

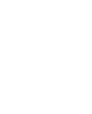

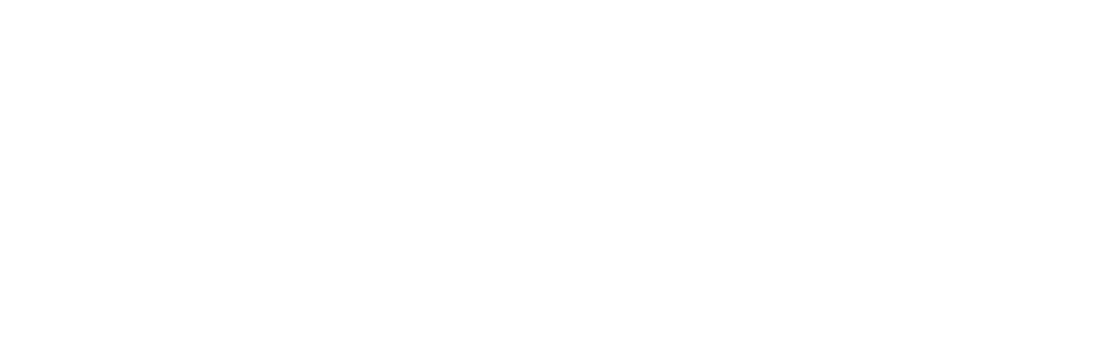

ches

(d)

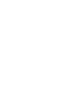

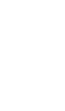

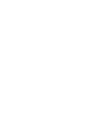

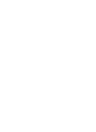

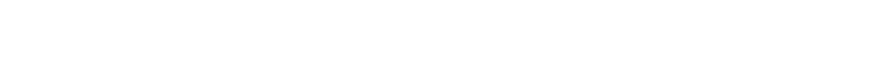


Supplementary Material
Click here to download Supplementary Material: Answer to editor.doc

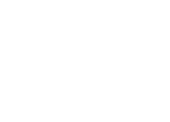

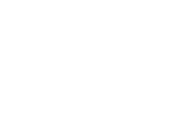

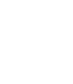

.

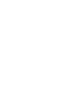

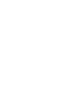

$\sqrt{10}$

.

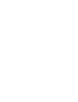

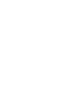

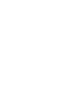

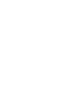

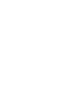

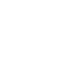

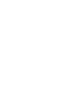
(1)

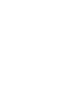
(1)

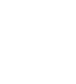

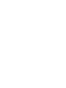
(1) . . . . . . . . . . . . . . . . 